\title{
幅厚比の大きい H形断面曲げ材の変形挙動予測に関する研究 POST-BUCKLING MOMENT-ROTATION BEHAVIOR OF THIN-WALLED I-SECTION MEMBERS
}

\author{
與田香二*，今井克彦**，黒羽啓明***，小川厚治**** \\ Kö̈ YODA, Katsuhiko IMAI, Yoshiaki KUROBANE and Ko $\ddot{i}$ OGAWA
}

\begin{abstract}
The use of thin-walled welded I-section members have proved to be a practical solution to achieve the best possible economy in construction of prefabricated large-span low-rise building frames in steel. In the design of such frames against strong earthquake motions, however, it is required to have accurate estimates of those deformation capacities of the members which are governed by local or lateral buckling or by both buckling modes frequently appearing simultaneously.

This paper presents a study for predicting moment-rotation relationships for thin-walled I-section beams and beam-columns after local and/or lateral buckling, when axial loads on these members are relatively low.

Firstly, an analysis based on yield line theory was attempted. The numerical results were compared with experimental results, which demonstrated a good agreement between them. Secondly, simple empirical formulas that were capable of predicting moment degradation curves after the maximum moments were devised and proposed on the basis of a number of numerical analyses performed over the parameter space covered by the database. Finally, a method to distinguish between members failing in a local buckling mode and those failing in a lateral buckling mode was discussed. By applying this method, an empirical formula to predict a boundary of member dimensions between which either of local or lateral buckling became decisive of the rotation capacity of members was proposed.
\end{abstract}

Keywords : welded I-section steel, bending member, deformation, local buckling, lateral buckling seismic design

1. 序

低層大スパン架構において, 部材の断面設計は, 鉛直 荷重による大きい曲げモーメントによって決定される。 このような架構での経済設計上の要点は, 部材断面を薄 肉化して，曲げに対する効率を高めることである。その ため柱・梁部材として，ランク $F D^{11}$ に分類される幅厚 比の大きい溶接 $\mathrm{H}$ 形銅が，多く用いられている。

筆者らは，このような架構の耐震設計に関する基礎資 料を得ることを目的として, 幅厚比の大きい溶接 $\mathrm{H}$ 形鋼 部材について, ウェブ, フランジの幅厚比, 横補剛間隔, モーメントこう配，および軸力比を変数とする曲げ実験 を行った。前報2)では, 実験の概要および結果を報告し た後, その結果に基づいて，終局耐力と変形挙動の評価 に関する検討を行った。

* 川鉄建材工業 (株) 熊本大学 大学院生

** 川鉄建材工業 (株) 技術研究所. 工博

*** 熊本大学 教授. 工博

**** 熊本大学 助教授・工博
しかし，最大耐力以後の劣化曲線のこう配に影響を与 える要因, および荷重一変形挙動の予測方法については, 検討が不十分であった。また，部材の終局状態において， 局部座屈と横座屈のどちらが支配的となるのか, その判 別方法についても検討が必要である。

本研究では, まず最大耐力以後の荷重一変形挙動を把 握するための解析方法を示し，実験結果との比較によっ て，その適用性を検討する。次に，実際的な部材寸法と 荷重条件を考慮した数多くの解析を行い, その結果より, 最大耐力以後の劣化こう配に関する予測式を導く。さら に, 解析結果および既往の実験結果をもとにして, 局部 座屈が支配的な部材と横座屈が支配的な部材の判別方法 を検討し，二つの座屈領域の境界を表す実験式を提案す る。

Kawatetsu Steel Products Co. Ltd., Graduate Student of Kumamoto Univ.

Technical Research Laboratory of Kawatetsu Steel Products Co. Ltd., Dr. Eng.

Professor of Kumamoto Univ., Dr. Eng.

Associate Professor of Kumamoto Univ., Dr. Eng. 


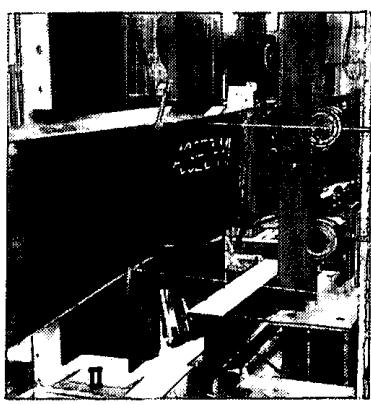

写真一1 横座届による変形

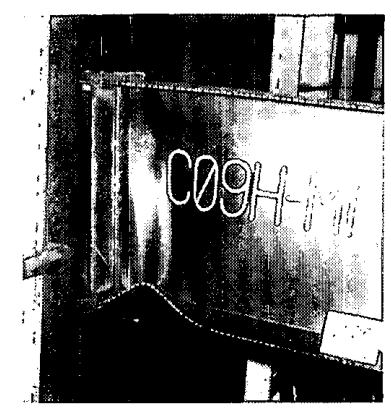

写真一2 局部座屈による変形

\section{2. 解 析}

本研究では降伏線理論に基づく解析を行い，最大耐力 以後の荷重一変形曲線を求める。降伏線理論はすでに, $\mathrm{H}$ 形鎆部材の局部座屈後あるいは横座屈後の挙動に関す る多くの研究に応用されている31-8)。以下に示す解析方 法では,これらの研究を参考にしている。

2-1 崩壊機構および仮定

前報2)では，単純梁に中央集中荷重を加える方法で， 曲げ実験を行った。実験中に観測された試験体の変形状 況を，写真一1および写真一2に示す。これらは，それ ぞれ横座屈が支配的な場合亡局部座屈が支配的な場合の 一例である。以下の記述において，これらを単に横座屈 部材および局部座屈部材と呼ぶことにするが，それぞれ の座屈による変形挙動は, 実験中の観測から次のような 性状を示すことが分かっている。

横座屈部材では，压縮フランジが部材中央の横補剛点 （荷重点）を中心とする $S$ 字形の横たわみを起こし，最
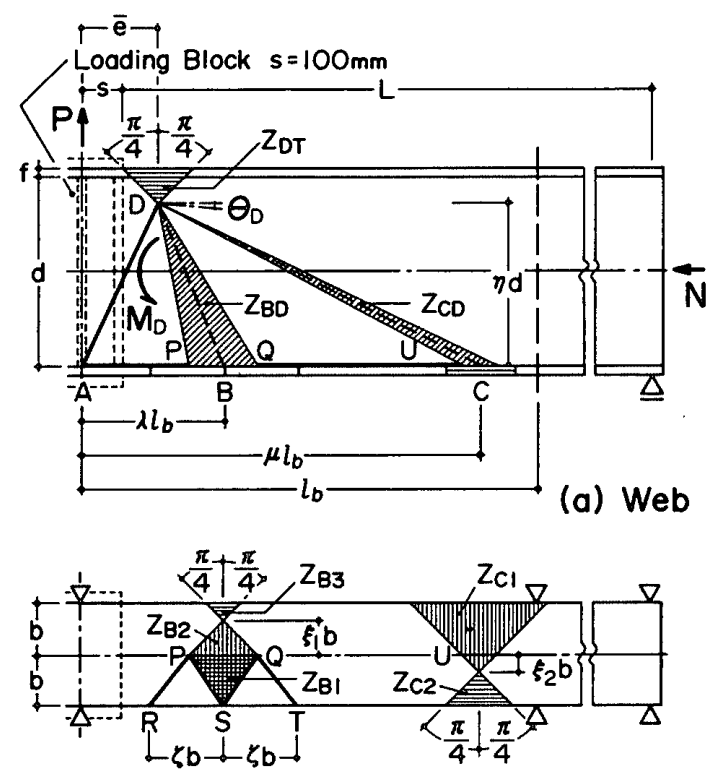

(b) Compression flange

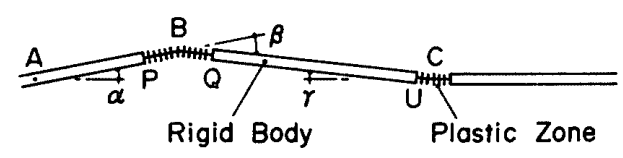

(c) Lateral deflection of web edge 图一1＼cjkstart横座屈による崩壊機構
大耐力に達する。その後, 写真一 1 に示すように，圧縮 フランジの最大横たわみ位置に局部座屈が発生し，それ によってさらに耐力が低下する。一方，写真一2に示す ような局部座屈部材では, 荷重点を間に置く両方の部材 のうちの片方に局部座屈が発生し耐力が低下すると，他 方には局部座屈は生じず, 塑性変形は座屈した方の部材 だけに集中する。その後，変形の増大に伴って，次第に 構面外変形（前報では, 局部座屈後の構面外変形亡呼ん, でいる) が大きくなる。

本解析では, 以上のような座屈による変形挙動をもと にして, 部材の崩壊機構を仮定した。

図一1および図一2は，それぞれ横座屈部材および鼠 部座屈部材についての崩壊機構である。板要素の変形は, 図中の太線部 (降伏線) およびハッチング部 (塑性化域) に集約され，ほかの部分は剛体である。横座屈部材では， 載荷ブロックを中心とする両側の圧縮フランジが，同時 に座屈するため, 両側にそれぞれ 2 箇所ずつのフランジ 面内の曲げ変形部分（B点, $\mathrm{C}$ 点）が生じて崩壊機構 が形成される。局部座屈部材においては, 載荷ブロック
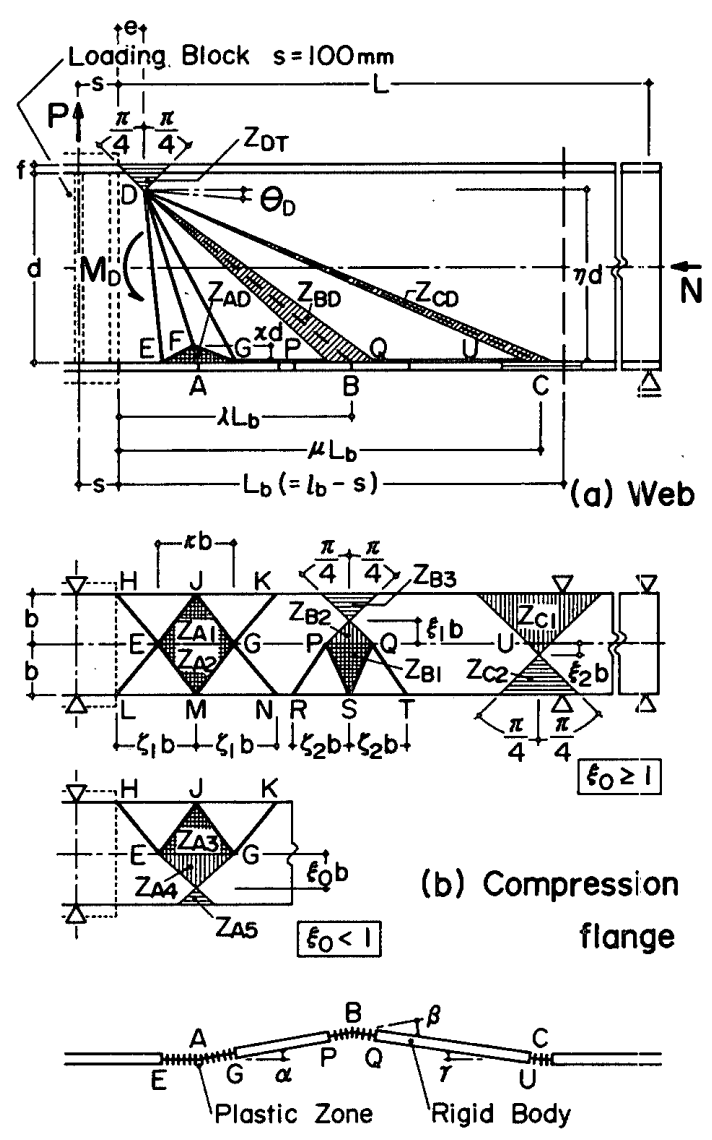

(c) Lateral deflection of web edge

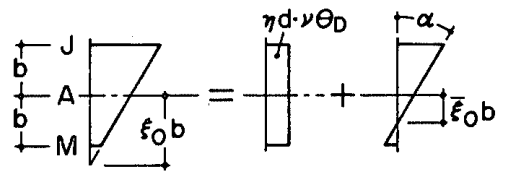

(d) Stain distribution at J-A-M line 图一2 局部來屈による崩壊機構 
を間にして片側だけに座屈による崩壊機構が形成され， 局部座屈後の構面外変形は, A, B, C, 3 箇所でのフラ ンジ面内の曲げ変形によって発生する。図一1 中の諸寸 法に乗じた $\zeta, \lambda, \mu$ ，および図一 2 中の $\zeta_{1}, x, \chi, \zeta_{2}, \lambda$, $\mu, \nu$ は, 後述する崩壊機構の決定に用いるための係数 である。同図の崩壊機構において, 次のような仮定が成 り立つものとする。

(1)材料は完全剛塑性体であり, von Mises の降伏条件に 従う。

(2)降伏線におけるせん断ひずみは無視できる。

(3)図中の横線部 (引張変形部), 縦線部 (王縮変形部) および斜線部（板要素の曲げを伴う王縮変形部）では， 一軸応力の状態にあり，降伏応力 $\sigma_{y}$ の下で塑性化して いる。斜線部において, 破線で示す降伏線は, 塑性化域 に囲まれているので内部仕事を行わないが，圧縮変形に よる内部仕事は，降伏線による内部仕事を下回ることは ないとする。

(4)図中の二重線部 (フランジとウェブの交線回りの回転 を伴う圧縮変形部) では, 二軸応力の状態で塑性化して いる。

(5)(3)および(4)の変形部分において, フランジとウェブの 交線は，塑性化域に囲まれているので曲げによる内部仕 事を行わない。

(6)引張フランジでは構面外変形が生じない。

(7)フランジの板厚は，断面せいに比べ十分小さい。

8)横座屈部材において, 圧縮フランジの荷重点を中心と するS字形の横たわみによって，載荷ブロックにねじれ 変形が生じ (写真一 1 参照), その周辺の変形も複雑な ものとなるが,これらの変形による仕事は, 図一1(a) に示す降伏線 $\mathrm{AD}$ および降伏線 $\mathrm{AP}$ の回転による仕事 によって置換できるものとする。一方，局部座屈部材に おいては，座屈した方にのみ変形が集中し，載荷ブロッ クには変形が生じないので, 載荷ブロックは剛体と考え る。

(9)板要素の崩壊機構は, 図中に $\eta d や \xi_{1} b$ などで示す中 立軸の移動によって変化するが，それによるひずみの戻 りは考えない。

(10図一1 および図一2のD点を通る断面では，外力（曲 げモーメント $M_{D}$ と軸圧縮力 $\left.N\right)$ に対して, 図一3(a) に示すような応力分布でつり合っている。 (11)図一1 および図一 2 の 点を通る断面では，板要素の 面外変形が生じていないので平面保持の仮定が成り立 ち, 図一3(b) に示すような応力分布で外力（曲げモー メント $M_{c}$ と軸圧縮力 $\left.N\right)$ とつり合っている。

(12)圧縮フランジの軸力は, 図一 $3(\mathrm{c})$ に示すように, D 点を通る断面と C 点の間で直線的に減少している。

(13)圧縮フランジの塑性化域において，フランジの面内曲 げ応力は, 図一3(d) のような矩形分布とする。したがっ

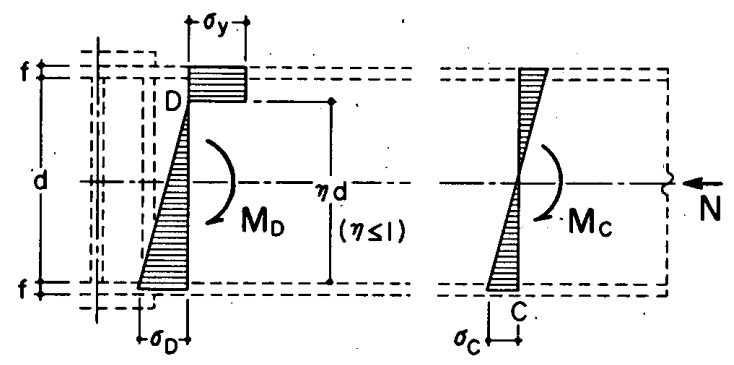

(a) about $D$

(b) above $\mathrm{C}$

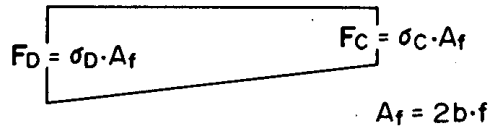

(c) Flange axial force

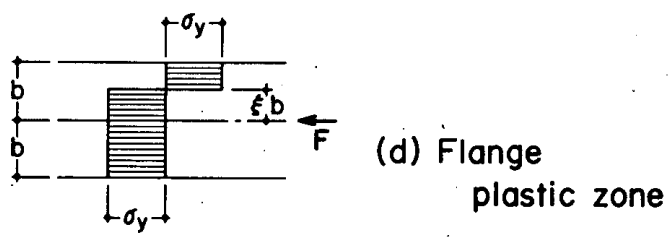

図一3 応力分布の仮定

て，この部分での軸力を(10)〜120の方法で求めることによ り，中立軸の位置 $\xi b($ 図一1および図一 2 における $\left.\xi_{1} b, \xi_{2} b, \bar{\xi}_{0} b\right)$ を定めることができる。

\section{2-2 解析の基礎}

i）外力による仕事率

図一1 および図一2に示された部材において，塑性回 転の中心（D 点）には，曲げモーメント $M_{D}$ と一定軸圧 縮力 $N$ が作用しており，これらの外力による仕事率 $W$ は次式で与えられる。

$$
W=M_{D} \cdot \dot{\theta}_{D}+N(\eta-0.5) d \cdot \dot{\theta}_{D}
$$

ここに， $\dot{\theta}_{D}:$ 部材の塑性回転中心における回転角速度, $d:$ ウブ幅, $\eta$ : ウェブ圧縮縁からの中立軸比。

ii）降伏線におけるエネルギー散逸率

降伏線に対して垂直方向の応力を $\sigma_{1}$, 平行方向の応 力を $\sigma_{2}$ とし，それぞれに対応するひずみ速度を $\dot{\varepsilon}_{1}$ およ び $\dot{\varepsilon}_{2}$ とすると，降伏条件，塑性流れ則，せん断ひずみ 無視の仮定，さらに降伏線が剛体部分に接しているので $\dot{\varepsilon}_{2}=0$ の条件より， $\sigma_{1}$ は次式で表される。

$$
\sigma_{1}= \pm(2 / \sqrt{3}) \cdot \sigma_{y}
$$

ここに， $\sigma_{y}:$ 対象とする板要素の降伏応力度。

材軸に対して角度 $\phi$ で傾いている降伏線が，材軸方 向の平均応力 $n \cdot \sigma_{y}$ を受けているとすると，降伏線に垂 直な応力は， $n \cdot \sigma_{y} \cdot \sin ^{2} \phi$ で表され，降伏線に作用する 単位長さ当たりの軸力 $N_{H}$ は次式となる。

$$
N_{H}=t \cdot n \cdot \sigma_{y} \cdot \sin ^{2} \phi
$$

ここに, $t:$ 板要素の厚さ。

板要素断面内の応力を矩形分布として, 板要素の圧縮 縁からの中立軸比 $\eta_{H}$, および単位長さ当たりの曲げモ一 メント $M_{H}$ を求めると, 


$$
\begin{aligned}
& \eta_{H}=0.5+(\sqrt{3} / 4) \cdot n \cdot \sin ^{2} \phi \\
& M_{H}=(2 / \sqrt{3}) \cdot \sigma_{y} \cdot t^{2}\left(1-\eta_{H}\right) \eta_{H}
\end{aligned}
$$

内力 $M_{H}$ および $N_{H}$ による降伏線部分のエネルギー散 冕率 $D_{H}$ は，（1）式と同㥞の方法で与えられ, 整理す ると次式のようになる。

$$
D_{H}=\frac{\sigma_{y} \cdot t^{2}}{2 \sqrt{3}}\left(1+\frac{3}{4} \cdot n^{2} \cdot \sin ^{4} \phi\right) l_{H} \cdot \dot{\rho}
$$

ここに， $l_{H}$ : 降伏線の長さ, $\dot{\rho}$ : 降伏線の回転角速度。

一方, 降伏線の回転による板要素の軸方向縮み $\Delta_{H}$ は, $\left(\eta_{H}-0.5\right) t \cdot \rho \cdot \sin \phi$ で表されるので，

$$
\Delta_{H}=(\sqrt{3} / 4) \cdot n \cdot \sin ^{3} \phi \cdot t \cdot \rho
$$

ここに, $\rho$ : 降伏線の回転角。

( 2 )(3) 式に含まれる $n$ は, 外力モーメントにつり 合う内部応力から求められるが，それを正確に評価しよ うとすると解法を複雑にしてしまう。そこで簡単のため に,ウェブにおいては, その影響を無視して $n=0$ とし, フラ゙ンジにおいては，材軸方向の応力が降伏応力にほぼ 等しいと考えて $n=1$ とする。

iii）一軸応力部分のエネルギー散逸率

材軸方向の応力 $\sigma_{1}$ のみによって塑性化している部分 では, 次式が成り立つ。

$$
\sigma_{1}= \pm \sigma_{y}
$$

$\sigma_{1}$ に対応するひずみ速度を $\dot{\varepsilon}_{1}$ とすると，この塑性化 域におけるエネルギー散逸率 $D_{A}$ は， $\sigma_{1} \cdot \dot{\varepsilon}_{1}$ を体積全体 にわたって積分することで与えられる。

$$
D_{A}=\int_{V} \sigma_{1} \cdot \dot{\varepsilon}_{1} d V
$$

塑性流れが起こっているときのエネルギー散逸率は， 常に正であるので9)，塑性化域において $\left|\dot{\varepsilon}_{1}\right|$ が一定なら ば，上式は次のように簡略化できる。

$$
D_{A}=\sigma_{y}\left|\dot{\varepsilon}_{1}\right| \cdot V
$$

ここに, $V:$ 塑性化域の体積。

\section{iv）二軸応力部分のエネルギー散冕率}

材軸方向の応力を $\sigma_{1}$, 材軸に垂直な方向の応力を $\sigma_{2}$ とし，それぞれに対応するひずみ速度を $\dot{\varepsilon}_{1}$ および $\dot{\varepsilon}_{2}$ と すると，塑性流れ則から，

$$
\frac{\dot{\varepsilon}_{2}}{\dot{\varepsilon}_{1}}=\frac{2 \sigma_{2} / \sigma_{1}-1}{2-\sigma_{2} / \sigma_{1}}
$$

（5）式を $\sigma_{2} / \sigma_{1}$ について解くと,

$$
\frac{\sigma_{2}}{\sigma_{1}}=\frac{2 \dot{\varepsilon}_{2}+\dot{\varepsilon}_{1}}{2 \dot{\varepsilon}_{1}+\dot{\varepsilon}_{2}}
$$

(6) 式の右辺を定数 Cとすると, (5)(6) 式は,

$$
\frac{\dot{\varepsilon}_{2}}{\dot{\varepsilon}_{1}}=\frac{2 C-1}{2-C}, \frac{\sigma_{2}}{\sigma_{1}}=C
$$

$\left(6^{\prime}\right)$ 式より $\sigma_{2}=C \cdot \sigma_{1}$ とおけるので, 降伏条件より $\sigma_{1}$ は, 次式で与えられる。

$$
\sigma_{1}=\frac{ \pm \sigma_{y}}{\sqrt{1-C+C^{2}}}
$$

一方，この塑性化域におけるエネルギ一散逸率 $D_{B}$ は,

$$
\begin{aligned}
D_{B} & =\int_{V}\left(\sigma_{1} \cdot \dot{\varepsilon}_{1}+\sigma_{2} \cdot \dot{\varepsilon}_{2}\right) d V \\
& =\int_{V} \sigma_{1} \cdot \dot{\varepsilon}_{1}\left(1+\frac{\sigma_{2}}{\sigma_{1}} \cdot \frac{\dot{\varepsilon}_{2}}{\dot{\varepsilon}_{1}}\right) d V
\end{aligned}
$$

上式に $\left(5^{\prime}\right)\left(6^{\prime}\right)(7)$ 式を代入し，(4) 式と同様に 簡略化すると，次式のように表される。

$$
D_{B}=\frac{2 \sqrt{1-C+C^{2}}}{2-C} \cdot \sigma_{y}\left|\dot{\varepsilon}_{1}\right| \cdot V
$$

ここに, $C=\left(2 \dot{\varepsilon}_{2}+\dot{\varepsilon}_{1}\right) /\left(2 \dot{\varepsilon}_{1}+\dot{\varepsilon}_{2}\right)$

v) 部材のモーメント一回転角関係

塑性変形部分のエネルギー散逸率の総和 $\Sigma D$ は,

$$
\sum D=\sum D_{H}+\sum D_{A}+\sum D_{B}
$$

で与えられる。仮想速度の原理から，上式と（1）式の

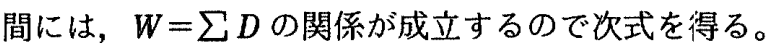

$$
M_{D} \cdot \dot{\theta}_{D}+N(\eta-0.5) d \cdot \dot{\theta}_{D}=\sum D
$$

したがって， $M_{D}$ は次のように表される。

$$
M_{D}=\Sigma D / \dot{\theta}_{D}-N(\eta-0.5) d
$$

上式中の $\sum D$ は，回転角 $\theta_{D}$ および回転角速度 $\dot{\theta}_{\mathrm{D}}$ か

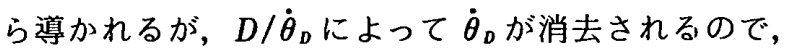
結局（9）式は，部材に作用する曲げモーメント $M_{D}$ （軸力とたわみによる 2 次曲げモーメントも含む）と部 材回転角 $\theta_{D}$ の関係を表していることになる。

\section{2-3 エネルギー散逸率の計算}

各塑性変形部分のエネルギー散逸率 $D_{H}, D_{A}, D_{B}$ を計 算するに当たって, 降伏線の $l_{H}, \sin \phi, \dot{\rho}$, および塑性 化域の $\dot{\varepsilon}_{1}, \dot{\varepsilon}_{2}, V$ を与える。

表一1は, 図一1 の横座屈部材における降伏線および 塑性化域について示したものである。同様にして表一2 では, 図一2 の局部座屈部材について示していぶが, 局 部座屈後の構面外変形によって生じる降伏線および塑性 化域については，表一1を参照して求めることができる ので省略している。

これらの表に示すように, $l_{H}, \sin \phi, V$ は幾何学的な

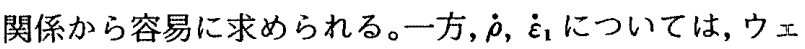
ブ圧縮縁の構面外変形によって生じる回転角速度 $\dot{\alpha}, \dot{\beta}$, $\dot{\gamma}$ (図一1(c), 図一2(c) 参照), およびフランジやウェ ブの局部座屈によって生じる回転角速度 $\dot{\omega}, \dot{\Omega}_{1}, \dot{\Omega}_{2}, \dot{\varphi}$ (図一4, 図一 5 参照) を求める必要がある。图に示す ようにこれらの回転角は, 材軸に平行で変形前の板要素 に垂直な平面に現れる三角形での, 幾何学的な閏係から 与えられる。

以下に,これらの回転角速度の算出方法を示す。また， 二軸応力による塑性化域では，材軸に垂直な方向のひず み速度 $\dot{\varepsilon}_{\varepsilon}$ も必要なので，その算出方法について述べる。

i) 構面外回転角速度 $\dot{\alpha}, \dot{\beta}, \dot{\gamma}$

図一 1 に示す横座屈部枌において, 回転角 $\theta_{0}$ による ウェブ生縮縁全体の軸方向縮み量は, 近似的に $\eta d \cdot \theta_{D}$ 
表一1 横座屈部材の塑性変形部分

\begin{tabular}{|c|c|c|c|}
\hline 降伏線 & \multicolumn{1}{|c|}{$l_{\mathrm{H}}$} & $\sin \phi$ & $\dot{\rho}$ \\
\hline $\mathrm{AD}$ & $\sqrt{(\eta \mathrm{d})^{2}+\overline{\mathrm{e}}^{2}}$ & $\frac{\eta \mathrm{d}}{l_{H}}$ & $\frac{\dot{\alpha}}{\sin \phi}$ \\
\hline $\mathrm{BD}$ & $\sqrt{(\eta \mathrm{d})^{2}+\left(\lambda l_{b}-\overline{\mathrm{e}}\right)^{2}}$ & $\frac{\eta \mathrm{d}}{l_{H}}$ & $\frac{\dot{\beta}}{\sin \phi}$ \\
\hline $\mathrm{CD}$ & $\sqrt{(\eta \mathrm{d})^{2}+\left(\mu l_{b}-\overline{\mathrm{e}}\right)^{2}}$ & $\frac{\eta \mathrm{d}}{l_{H}}$ & $\frac{\dot{r}}{\sin \phi}$ \\
\hline $\mathrm{AP}$ & $\lambda l_{b}-\xi_{1} \mathrm{~b}$ & 0 & $\dot{\alpha} \frac{\overline{\mathrm{e}}}{\eta \mathrm{d}}$ \\
\hline $\mathrm{QU}$ & $(\mu-\lambda) l_{b}-\left(\xi_{1}+\xi_{2}\right) \mathrm{b}$ & 0 & $\dot{r} \frac{\mu l_{\mathrm{b}}-\overline{\mathrm{e}}}{\eta \mathrm{d}}$ \\
\hline $\mathrm{PR}, \mathrm{QT}$ & $\mathrm{b} \sqrt{1+\left(\zeta-\xi_{1}\right)^{2}}$ & $\frac{\mathrm{b}}{l_{H}}$ & $\frac{\dot{\omega}}{\sin \phi}$ \\
\hline $\mathrm{PS}, \mathrm{QS}$ & $\mathrm{b} \sqrt{1+\xi_{1}{ }^{2}}$ & $\frac{\mathrm{b}}{l_{H}}$ & $\frac{\dot{\omega}}{\sin \phi}$ \\
\hline
\end{tabular}

\begin{tabular}{|c|c|c|}
\hline 塑性化域 & $\dot{\varepsilon}_{1}$ & v \\
\hline$Z_{B D}$ & $\frac{\dot{\beta}}{2}$ & $\xi_{1} b \cdot \eta d \cdot w$ \\
\hline$Z_{C D}$ & $\frac{\dot{r}}{2}$ & $\xi z_{2} b \cdot \eta d \cdot \mathbb{W}$ \\
\hline$Z_{D T}$ & $-\frac{\dot{\theta}_{D}}{2}$ & $2 \mathrm{~b} \cdot \mathrm{f}\{\mathrm{f}+2(1-\eta) \mathrm{d}\}+w\{(1-\eta) \mathrm{d}\}^{2}$ \\
\hline$Z_{B i}$ & $\frac{\dot{\beta}}{2}$ & $\xi_{1} b^{2} \cdot f$ \\
\hline$Z_{\mathrm{B} 2}$ & $\frac{\dot{\beta}}{2}$ & $(\xi, 1 b)^{2} \cdot f$ \\
\hline$Z_{B 3}$ & $-\frac{\dot{\beta}}{2}$ & $\left|\left(1-\xi_{1}\right) b\right|^{2} \cdot f$ \\
\hline$Z_{c 1}$ & $\frac{\dot{r}}{2}$ & $\{(1+\xi 2) b\}^{2} \cdot f$ \\
\hline$Z_{c 2}$ & $-\frac{\dot{r}}{2}$ & $\left\{\left(1-\xi_{2}\right) b\right\}^{2} \cdot f$ \\
\hline
\end{tabular}

$l_{\mathrm{H}}$ : 降伏線の長さ， $\phi:$ 降伏線と材軸のなす角度， $\dot{\rho}:$ 降伏線の 回云角速度， $\dot{\varepsilon}_{1}$ : 材軸方向のひずみに对応するひずみ速度（任縮 側を正とする），V：塑性化域の体䅡， $\mathrm{d} ：$ ウェブ幅，b：フラン ジ半幅, $w:$ ウェフ板厚, $\mathrm{f}:$ フランジ板厚, $l_{b}$ : 横補剛間隔, $\mathrm{s}$ : 载荷ブロックの長さの $1 / 2, \overline{\mathrm{e}}=\mathrm{s}+\mathrm{f}+(1-\eta) \mathrm{d}, \zeta, \lambda, \mu, \eta$, $\xi_{1}, \xi_{2}$ : 図一1参照, $\dot{\theta}_{\mathrm{D}}, \dot{\alpha}, \dot{\beta}, \dot{\gamma}, \dot{\omega}:$ 园 -1 おょび图 $-4(\mathrm{a})$ に示す回転角 $\theta_{\mathrm{D}} ， \alpha ， \beta ， \gamma ， \omega$ のそれぞれに対応する回転角速度.

で与えられる。この縮み量に適合するように，塑性化域 が変形し，魝体部分が構面外に回転するわけである（同 図 (c) 参照)。したがって, 塑性化域の変形および剛体 部分の回転による軸方向縮み量をそれぞれ $\Delta_{P}, \Delta_{R}$ とす ると次式が成り立つ。

$$
\eta d \cdot \theta_{D}=\Delta_{P}+\Delta_{R}
$$

ここに, $\Delta_{P}=\xi_{1} b \cdot \beta+\xi_{2} b \cdot \gamma$

$$
\begin{aligned}
\Delta_{R} & =l_{A P}(1-\cos \alpha)+l_{Q U}(1-\cos \gamma) \\
& \doteqdot l_{A P} \cdot \alpha^{2} / 2+l_{Q U} \cdot \gamma^{2} / 2 \\
l_{A P} & =\lambda l_{b}-\xi_{1} b \\
l_{Q U} & =(\mu-\lambda) l_{b}-\left(\xi_{1}+\xi_{2}\right) b
\end{aligned}
$$

一方，B点の横たわみは， $\alpha$ と $\gamma$ のそれぞれを用い て表せることから，近似的に次式が得られる。

$$
\lambda l_{b} \cdot \alpha=(\mu-\lambda) l_{b} \cdot \gamma
$$

\begin{tabular}{|c|c|c|}
\hline 塑性化域 & $\dot{\varepsilon}_{1}$ & V \\
\hline$Z_{A D}$ & $\frac{\bar{\xi}_{0}}{\kappa} \dot{\alpha}+\frac{\eta \mathrm{d}}{\kappa \mathrm{b}} \nu \dot{\theta}_{\mathrm{D}}$ & $\frac{1}{2} \times b \cdot x d \cdot w$ \\
\hline$Z_{a 1}$ & $\frac{\bar{\xi}_{0}}{\kappa} \dot{\alpha}+\frac{\eta \mathrm{d}}{\kappa \mathrm{b}} \nu \cdot \dot{\theta}_{\mathrm{D}}$ & $\frac{1}{2} \kappa b^{2} \cdot f$ \\
\hline$Z_{A 2}$ & $\frac{\bar{\xi}_{\mathrm{a}}}{\kappa} \dot{\alpha}+\frac{\eta \mathrm{d}}{\kappa \mathrm{b}} \nu \dot{\theta}_{\mathrm{D}}$ & $\frac{1}{2} x \mathrm{~b}^{2} \cdot \mathrm{f}$ \\
\hline$Z_{A 3}$ & $\frac{\bar{\xi}_{0}}{\kappa} \dot{\alpha}+\frac{\eta d}{\kappa b} \nu \dot{\theta}_{0}$ & $\frac{1}{2} \times b^{2} \cdot f$ \\
\hline$Z_{A 4}$ & $\frac{\bar{\xi}}{x} \dot{\alpha}+\frac{\eta \mathrm{d}}{x \mathrm{~b}} \cdot \nu \dot{\theta}_{\mathrm{D}}$ & $\frac{1}{2} \kappa b \cdot \xi_{0} b \cdot f$ \\
\hline$Z_{A 5}$ & $-\frac{\bar{\xi}_{0}}{\kappa} \dot{\alpha}-\frac{\eta \mathrm{d}}{\kappa \mathrm{b}} \nu \dot{\theta}_{\mathrm{D}}$ & $\frac{1}{2} \kappa b^{2} \cdot \frac{\left(1-\xi_{0}\right)^{2}}{\xi_{0}} \cdot f$ \\
\hline
\end{tabular}

上式および, $\beta=\alpha+\gamma$ の関係から，

$$
\beta=k_{\mathrm{B}} \cdot \alpha, \quad \gamma=k_{c} \cdot \alpha
$$

表一2 局部座屈部材の塑性変形部分

\begin{tabular}{|c|c|c|c|}
\hline 降优線 & \multicolumn{1}{|c|}{$l_{\mathrm{H}}$} & $\sin \phi$ & $\dot{\rho}$ \\
\hline $\mathrm{DE}$ & $\sqrt{(\eta \mathrm{d})^{2}+\left(\zeta, \mathrm{b}-\frac{\kappa \mathrm{b}}{2}-\mathrm{e}\right)^{2}}$ & $\frac{\eta \mathrm{d}}{l_{\mathrm{H}}}$ & $\frac{\psi}{\sin \phi}$ \\
\hline $\mathrm{DF}$ & $\left(1-\frac{x}{\eta}\right) \sqrt{(\eta \mathrm{d})^{2}+\left(\zeta_{1} \mathrm{~b}-\mathrm{e}\right)^{2}}$ & $\frac{\eta \mathrm{d}-x \mathrm{~d}}{l_{\mathrm{H}}}$ & $\frac{2 \psi+\dot{\alpha}}{\sin \phi}$ \\
\hline $\mathrm{DG}$ & $\sqrt{(\eta \mathrm{d})^{2}+\left(\zeta, \mathrm{b}+\frac{\kappa \mathrm{b}}{2}-\mathrm{e}\right)^{2}}$ & $\frac{\eta \mathrm{d}}{l_{\mathrm{H}}}$ & $\frac{\psi}{\sin \phi}$ \\
\hline $\mathrm{EF}$ & $\sqrt{(x \mathrm{~d})^{2}+\left\{\frac{\kappa \mathrm{b}}{2}-\left(\zeta_{1} \mathrm{~b}-\mathrm{e}\right) \frac{x}{\eta}\right\}^{2}}$ & $\frac{x \mathrm{~d}}{l_{\mathrm{H}}}$ & $\frac{\psi}{\sin \phi}$ \\
\hline $\mathrm{FG}$ & $\sqrt{(x \mathrm{~d})^{2}+\left(\frac{\kappa \mathrm{b}}{2}+\left(\zeta_{1} \mathrm{~b}-\mathrm{e}\right) \frac{x}{\eta}\right\}^{2}}$ & $\frac{x \mathrm{~d}}{l_{H}}$ & $\frac{\psi}{\sin \phi}$ \\
\hline EH, GK & $\mathrm{b} \sqrt{1+\left(\zeta,-\frac{1}{2} \kappa\right)^{2}}$ & $\frac{\mathrm{b}}{l_{\mathrm{H}}}$ & $\frac{\dot{\dot{\Omega}}}{\sin \phi}$ \\
\hline EJ, GJ & $\mathrm{b} \sqrt{1+\frac{1}{4} \kappa^{2}}$ & $\frac{\mathrm{b}}{l_{\mathrm{H}}}$ & $\frac{\dot{\Omega}_{1}}{\sin \phi}$ \\
\hline EL. GN & $\mathrm{b} \sqrt{1+\left(\zeta_{1}-\frac{1}{2} \kappa\right)^{2}}$ & $\frac{\mathrm{b}}{l_{H}}$ & $\frac{\dot{\Omega}_{2}}{\sin \phi}$ \\
\hline EM, GM & $\mathrm{b} \sqrt{1+\frac{1}{4} \kappa^{2}}$ & $\frac{\mathrm{b}}{l_{H}}$ & $\frac{\dot{\Omega}_{2}}{\sin \phi}$ \\
\hline
\end{tabular}

$l_{\mathrm{H}}$ : 降伏線の長さ， $\phi:$ 降伏線と材軸のなす角度, $\dot{\rho}:$ 降伏線の 回転角速度， $\dot{\varepsilon}_{1}$ ：材軸方向のひずるに対応するひずみ速度（殴縮 側を正とする)，V：塑性化域の体皘，d：ウェブ幅，b：フラン ジ半幅。 w：ウェブ板厚, $f:$ フランジ板厚, $e=f+(1-\eta) d$, $\xi_{1}, \kappa, x, \eta, \bar{\xi}_{0}, \xi_{0}$ : 図 -2 参照, $\dot{\theta}_{0}, \dot{\alpha}, \dot{\Omega}_{1}, \dot{\Omega}_{2}, \psi:$ 图 -2 , 図一 4 (b)および図一 5 に示す回転角 $\theta_{0} ， \alpha ， \Omega_{1} ， \Omega_{2} ， \psi$ のそれぞれ に奶応する回転角速度.

ここに, $k_{B}=\mu /(\mu-\lambda), \quad k_{c}=\lambda /(\mu-\lambda)$

（11）式を（10）式に代入すると，次のような $\alpha$ に関 する 2 次方程式が得られる。

$$
A \cdot \alpha^{2}+B \cdot \alpha-\eta d \cdot \theta_{D}=0
$$

ここに, $A=\left(l_{A P}+l_{Q U} \cdot k_{c}^{2}\right) / 2$

$$
B=b\left(\xi_{1} \cdot k_{B}+\xi_{2} \cdot k_{c}\right)
$$

上式を $\alpha$ について解くと,

$$
\alpha=\left(-B \pm \sqrt{B^{2}+4 A \cdot \eta d \cdot \theta_{D}}\right) /(2 A) \text {. }
$$

この 2 根のうち, 小さい方は負となるので, 大きい方 が有意な解である。(12) 式より, 回転角 $\alpha$ に対応する 回転角速度 $\dot{\alpha}$ は，次式で与えられる。

$$
\dot{\alpha}=\eta d \cdot \dot{\theta}_{D} / \sqrt{B^{2}+4 A \cdot \eta d \cdot \theta_{D}}
$$

回転角 $\beta, \gamma$ に対応する回転角速度 $\dot{\beta}, \dot{\gamma}$ は, (11) 式 から次式で与えられる。

$$
\dot{\beta}=k_{B} \cdot \dot{\alpha}, \quad \dot{\gamma}=k_{c} \cdot \dot{\alpha}
$$

図一 2 に示す局部座屈部材においては，D点での部材 
回転角 $\theta_{D}$ を, 構面内変形によって吸収される成分 $\nu \theta_{D}$ と, 構面外変形によって吸収される成分 $(1-\nu) \theta_{D}$ に分 解して扱う。ここで, 係数 $\nu$ は 0 1 の範囲で変化する 量であり, $\nu=0$ のとき構面外変形のみが生じ， $\nu=1$ の とき載荷ブロックに接する局部座屈部分での構面内変形 のみが生じる。

したがって, 図一2(c) に示すウェブ玨縮縁の構面外 変形では, 縮み量 $\eta d(1-\nu) \theta_{D}$ に対する変形の適合を考 えることで, 横座屈部材と同様にして $\alpha, \beta, \gamma$ が求めら れる。ただしこの場合, 塑性化域 E-G 間での軸方向 縮みは，同図 (d) に示すように， $\bar{\xi}_{0} b \cdot \alpha$ で与えられる ことに注意を要する。ここで $\bar{\xi}_{0} b$ は, 図一 3 で仮定した 応力分布から求められる, 圧縮フランジの仮想の中立軸 の位置である。

ii）三角形 RST での回転角速度 $\dot{\omega}$

図一 1 に示す横座屈部材の王縮フランジのB点に, 構 面外回転角 $\beta$ が生じることによって，フランジ縁に三 角形 RST が現れる（図一4(a) 参照)。点 R-S 間に生 じる全軸方向縮みを $\zeta b \cdot \varepsilon_{f}$, 降伏線に生じる軸方向縮み を $\zeta b \cdot \varepsilon_{h}$ で表すと, 回転角 $\omega$ との間に次式が成り立つ。 $\cos \omega=\left(1-\varepsilon_{f}\right) /\left(1-\varepsilon_{h}\right)$

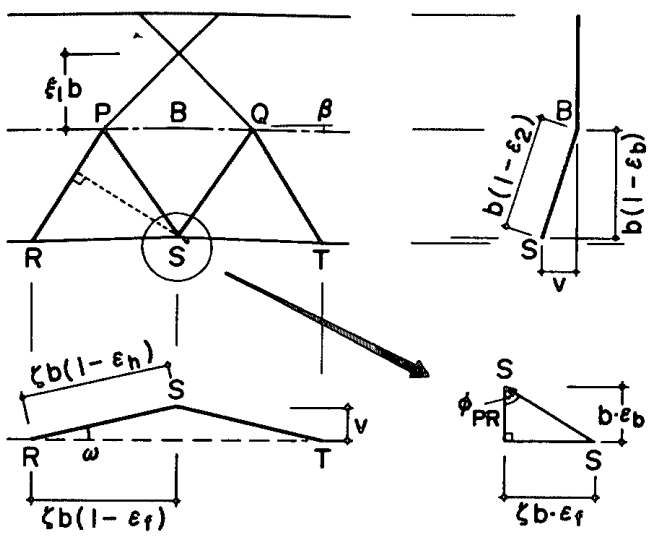

(a) Flange buckling about $B$

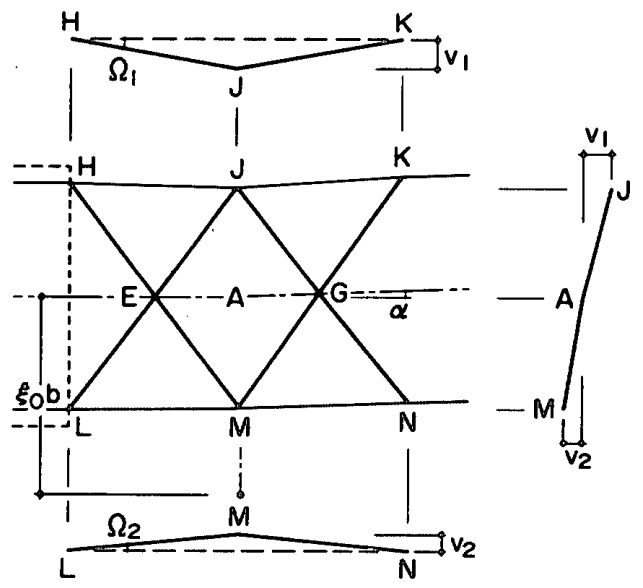

(b) Flange buckling about $A$

図一4 フランジ板要素の変形
上式に, $\cos \omega \fallingdotseq 1-\omega^{2} / 2$ の関係を用い, 3 次の項を 省略すると,

$$
\omega^{2} / 2+\varepsilon_{h}-\varepsilon_{\rho}=0
$$

降伏線 PR, PS での回転角 $\rho_{\mathrm{PR}}, \rho_{\mathrm{PS}}$ は, 表一1(a)に 示すように, それぞれ $\omega / \sin \phi_{\mathrm{PR}}, \omega / \sin \phi_{\mathrm{PS}}\left(\phi_{\mathrm{PR}}, \phi_{\mathrm{PS}}\right.$ :それぞれ降伏線 PR，PS と材軸のなす角度）で表さ れる。また，降伏線に生じた軸方向縮み $\zeta b \cdot \varepsilon_{h}$ は，（ 3 ) 式で求められるので,

$$
\varepsilon_{h}=\frac{\sqrt{3} \cdot f}{4 \zeta b} n \cdot \omega\left(\sin ^{2} \phi_{\mathrm{PR}}+\sin ^{2} \phi_{\mathrm{PS}}\right)
$$

ただし，フランジに対して， $n=1$ とする。

$\mathrm{RS}$ 間に生じる全軸方向縮み $\zeta b \cdot \varepsilon_{s}$ は, $\left(1+\xi_{1}\right) b \cdot \beta / 2$ で表せるので,

$$
\varepsilon_{f}=\beta\left(1+\xi_{1}\right) /(2 \zeta)
$$

以上より， $\omega$ に関する 2 次方程式が得られる。

$$
\omega^{2}+A \cdot \omega-B \cdot \beta=0
$$

ここに, $A=\{\sqrt{3} f /(2 \zeta b)\} \cdot\left(\sin ^{2} \phi_{\mathrm{PR}}+\sin ^{2} \phi_{\mathrm{PS}}\right)$

$$
B=\left(1+\xi_{1}\right) / \zeta
$$

$\omega$ は正值でなければならないから,上式の有意な解は，

$$
\omega=\left(-A+\sqrt{A^{2}+4 B \cdot \beta}\right) / 2 \cdots
$$

したがって，回転角 $\omega$ に対応する回転角速度は，

$$
\dot{\omega}=B \cdot \dot{\beta} / \sqrt{A^{2}+4 B \cdot \beta}
$$

図一 2 に示す局部座屈部材において, 三角形 RST で

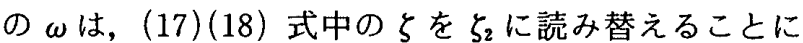
よって，そのまま用いることができる。また，載荷ブロッ クに接する王縮フランジに現れる, 三角形 $\mathrm{HJK}_{n}, \mathrm{LMN}$ での回転角 $\Omega_{1} ， \Omega_{2}$ については，図一4(b) に示すように， それぞれのフランジ縁での軸方向縮みが， $\left(\xi_{0}+1\right) b \cdot \alpha$, $\left(\xi_{0}-1\right) b \cdot a$ となることから，(17)(18) 式を導いた方法 と同様にして求められる。ただし $\xi_{0} b$ は, 図一2(d) より, 次式で表される。

$$
\xi_{0} b=\bar{\xi}_{0} b+\eta d \cdot \nu \theta_{D} / \alpha
$$

iii）三角形 $E^{\prime} F G^{\prime}$ での回転角速度 $\dot{\Psi}$

図一2(a) に示す局部座屈部材のウェブ座屈部分にお

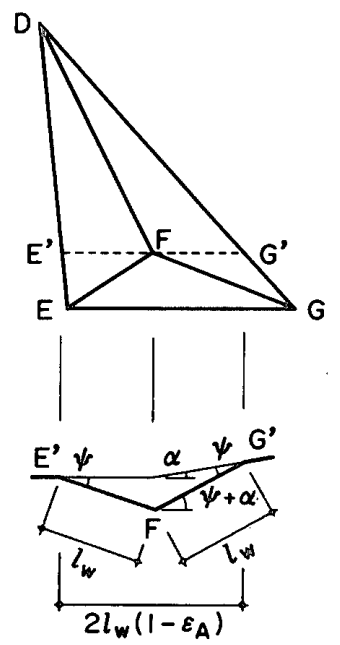

図一5 ウェブ板要素の変形 
いて，F点を通ってフランジに平行な平面には，三角 形 $\mathrm{E}^{\prime} \mathrm{FG} G^{\prime}$ が現れる。図一5に示すように，線分 $\mathrm{E}^{\prime} \mathrm{F}$ お よび線分 $\mathrm{FG}^{\prime}$ の長さを $l_{w}$, 点 $\mathrm{E}^{\prime}-\mathrm{G}^{\prime}$ 間の軸方向ひす みを $\varepsilon_{A}$ とする亡，回転角 $\Psi$ を用いて，

$l_{w} \cos \Psi+l_{w} \cos (\Psi+\alpha)=2 l_{w}\left(1-\varepsilon_{A}\right)$

上式の $l_{w}$ は消去できる。また, $\cos \Psi \fallingdotseq 1-\Psi^{2} / 2$ の 関係 $(\cos (\Psi+\alpha)$ も同様) を用いて整理すると,

$$
\Psi^{2}+\alpha \cdot \Psi+\alpha^{2} / 2-2 \varepsilon_{A}=0
$$

この 2 次方程式から得られる $\Psi$ の有意な解は,

$$
\Psi=\sqrt{2 \varepsilon_{A}-\alpha^{2} / 4}-\alpha / 2
$$

したがって，回転角 $\Psi$ に対応する回転角速度は,

$$
\dot{\Psi}=\frac{\dot{\varepsilon}_{A}-\alpha \dot{\alpha} / 4}{\sqrt{2 \varepsilon_{A}-\alpha^{2} / 4}}-\frac{\dot{\alpha}}{2} .
$$

ここに, $\varepsilon_{A}=\bar{\xi}_{0} \alpha / x+\eta d \cdot \nu \dot{\theta}_{D} /(x b)$

$$
\dot{\varepsilon}_{A}=\bar{\xi}_{0} \dot{\alpha} / x+\eta d \cdot \nu \dot{\theta}_{D} /(x b)
$$

iv）塑性化域 $Z_{B 1}$ でのひずみ速度 $\dot{\varepsilon}_{2}$ 、

二軸応力によって塑性化する部分での，材軸に垂直な

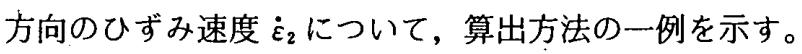

図一4(a) に示すように，材軸に垂直な線分 BS の変 形後の長さを $b\left(1-\varepsilon_{2}\right)$ とし, その長さを変形前のフラ ンジ面に投影したものを $b\left(1-\varepsilon_{b}\right)$ とすると, $\mathrm{S}$ 点での たわみ $v$ が線分 $\mathrm{RS}$ の変形からも表せることからら,

$$
\left(1-\varepsilon_{2}\right)^{2}-\left(1-\varepsilon_{b}\right)^{2}=\zeta^{2}\left\{\left(1-\varepsilon_{h}\right)^{2}-\left(1-\varepsilon_{f}\right)^{2}\right\}
$$

簡単のために上式の 2 次の項を省略し，(15）式を用 いると，次のように整理できる。

$$
\varepsilon_{2}=\varepsilon_{b}-\zeta^{2} \cdot \omega^{2} / 2
$$

したがって，ひずみ速度 $\dot{\varepsilon}_{2}$ は，次式で与えられる。

$$
\dot{\varepsilon}_{2}=\dot{\varepsilon}_{b}-\zeta^{2} \cdot \omega \cdot \dot{\omega} \cdot
$$

降伏線 PR の回転に伴うS 点の軌跡は, $\mathrm{S}$ 点を通って 降伏線 PR に垂直な平面上にあるので，その移動量の 材軸方向成分が $\zeta b \cdot \varepsilon_{f}$ であり，材軸に垂直な方向の成 分が $b \cdot \varepsilon_{b}$ であるという関係から，

$$
\varepsilon_{b}=\zeta \cdot \varepsilon_{f} / \tan \phi_{\mathrm{PR}}=\zeta\left(\zeta-\xi_{1}\right) \varepsilon_{f}
$$

$\varepsilon_{f}$ は, (16) 式で表されるので,

$$
\varepsilon_{b}=\left(\zeta-\xi_{1}\right)\left(1+\xi_{1}\right) \cdot \beta / 2
$$

上式を用いて $(22)$ 式を表すと, 次式となる。

$$
\dot{\varepsilon}_{2}=\left(\zeta-\xi_{1}\right)\left(1+\xi_{1}\right) \cdot \dot{\beta} / 2-\zeta^{2} \cdot \omega \cdot \dot{\omega}
$$

2-4 解 法

\section{i ）崩壊機構の決定}

( 9 ) 式より得られる $M_{D}$ は, 真の崩壊荷重に対して上 界となるので， $M_{D}$ が最小となるように崩壊機構を定め る必要がある。そこで，横座屈部材においては図一1に 示す係数 $\zeta, \lambda, \mu$ を用いて, 局部座屈部材においては図 -2 に示す係数 $\zeta_{1}, x, \chi, \zeta_{2}, \lambda, \mu, \nu$ を用いて $M_{D}$ の最小 化を行い，これらの係数の最適解を求める。ここで，係 数 $\lambda, \mu$ は構面外変形による部材全体の崩壊機構を表し, 係数 $\zeta, \zeta_{2}$ は, 構面外変形に伴って発生するフランジ局 部座屈による板要素の崩壊機構を表している。局部座屈
部材の係数 $\zeta_{1}, x, \chi$ は，載荷ブロックに接する局部座屈 部分でのフランジとウェブの崩壊機構を表し，係数 $\nu$ は前述したように，局部座屈部材の回転角 $\theta_{D}$ のうち， 構面内変形によって吸収される成分の比率を表してい る。

荷重 $M_{D}$ の最小值を与えるこれらの係数の值は，回転 角 $\theta_{D}$ の増大に伴って変化するが, 各回転角 $\theta_{D}$ ごとに最 小化を行うと計算量が膨大になるので，ある $\theta_{D}$ の值に ついてのみ最小化を行う。ただし，局部座屈部材につい ては係数が多いので,まず $\nu=1$ (構面外変形は起こら ないから係数 $\zeta_{2}, \lambda, \mu$ は不要) として最小化を行い係数 $\zeta_{1}, x, \chi$ を定め, 次に $\nu=0$ として係数 $\zeta_{2}, \lambda, \mu$ による 最小化を行って，これらの係数を求める。

最小化の手法としては，直接探索法(10)を用いる。この 方法は, ある部材回転角 $\theta_{0}$ に対する $(9)$ 式の関数值 (.崩 壊荷重 $M_{D}$ ) を，上記の係数を少しずつ変化させて逐次 求めて行き，関数の極小点を探索するものである。この 方法では導関数を用いないので，解法を簡潔にすること ができる。

以上の操作によっで荷重 $M_{D}$ が変化すると, 図一3で 仮定した部材の内部応力分布も変化するので，それに適 合するように, 中立軸の位置を表す係数 $\eta, \xi_{1}, \xi_{2}, \bar{\xi}_{0}$ を 修正する。この修正によっても崩壊機構が変化するため, 荷重 $M_{D}$ を最小化し直す必要がある。このように，崩壊 機構は, 荷重 $M_{D}$ の最小化亡内部応力分布の修正を交互 に, 荷重 $M_{D}$ が許容誤差の範囲内に収束するまで繰り返 すことによって決定される。

\section{ii）荷重一変形関係}

崩壊機構を決定した後, 回転角 $\theta_{D}$ を順次増加させて 各回転角ごとに荷重 $M_{D}$ を算出することによって $M_{D}$ と $\theta_{D}$ の関係が求められる。ただし，局部座屈部材におい

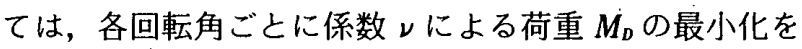
行う。このことによって, 構面外変形の発生および進展 を表現し，その影響を見ることができる。

このような操作によって荷重 $M_{D}$ が変化するので, こ こでも係数 $\eta, \xi_{1}, \xi_{2}, \bar{\xi}_{0}$ の修正を行う。したがって，荷 重の算出（あるいは最小化）とこれらの係数の修正を交 互に繰り返して収束させることによって, 各回転角ごと の荷重を求める。

以上により，図一1 および図一 2 に示す部材の回転中 心 D点における曲げモーメント $M_{D}$ と部材回転角 $\theta_{D}$ の 関係が与えられる。一方，前報 ${ }^{2}$ の実験結果では，載荷 ブロックに接する位置での曲げモーメント $M$ と部材回 転角 $\theta$ の関係を表している。したがって, 実験結果と 解析結果が比較できるように，次式を用いて，解析より 求めた $M_{D}-\theta_{D}$ 関係を $M-\theta$ 関係にあらためる。

$$
\begin{aligned}
& M=M_{D} \cdot L /(L-e)-e \cdot \theta_{D} \cdot N \\
& \theta=(1-e / L) \cdot \theta_{D} \ldots \ldots \ldots \ldots \ldots \ldots \ldots
\end{aligned}
$$


表一3 解析条件および解析による崩壊機構

\begin{tabular}{|c|c|c|c|c|c|c|c|c|c|c|c|c|c|c|c|}
\hline $\begin{array}{l}\text { 坐屈 } \\
\text { 形式 }\end{array}$ & 試験体名 & $\begin{array}{c}\mathrm{H} \\
\mathrm{mm} \\
\end{array}$ & $\begin{array}{c}\mathrm{B} \\
\mathrm{m} \text { 田 } \\
\end{array}$ & $\begin{array}{c}\mathrm{w} \\
\mathrm{mm} \\
\end{array}$ & $\begin{array}{c}f \\
\mathrm{mam}\end{array}$ & $\begin{array}{l}l_{b} \\
\mathrm{~mm}\end{array}$ & $\frac{M_{2}}{M_{1}}$ & $\frac{N}{N_{y}}$ & $\begin{array}{l}\zeta_{2} \text { or } \\
\zeta_{2}\end{array}$ & $\lambda$ & $\mu$ & \multicolumn{2}{|c|}{$\begin{array}{c}\text { 板厚 } \\
\mathrm{mm}\end{array}$} & \multicolumn{2}{|c|}{$\begin{array}{r}\text { 降伏点 } \\
t / \mathrm{cm}^{2}\end{array}$} \\
\hline \multirow{7}{*}{ 横 } & A09E0-H1 & 405.5 & 107.9 & 4.44 & \multirow{7}{*}{ 5. 89} & 2703 & \multirow{7}{*}{0.0} & \multirow{7}{*}{0.0} & 1.54 & 0.172 & 0.441 & \multirow{3}{*}{\multicolumn{2}{|c|}{$\begin{array}{l}3.23 \\
4.44 \\
5.89 \\
\end{array}$}} & \multicolumn{2}{|c|}{2.86} \\
\hline & $\mathrm{A} 12 \mathrm{E} 0-\mathrm{ML}$ & 539. 4 & 108.0 & 4. 44 & & 1949 & & & 1. 47 & 0.333 & 0.729 & & & \multicolumn{2}{|c|}{ 3. 10} \\
\hline & B09E0-H1 & 404.6 & 143. 6 & 4. 44 & & 4240 & & & 1. 48 & 0.117 & 0.362 & & & \multicolumn{2}{|c|}{ 3. 09} \\
\hline & $\mathrm{B} 12 \mathrm{E} 0-\mathbb{1 1}$ & 539.6 & 143. 6 & 4. 44 & & 2959 & & & 1. 48 & 0.233 & 0.596 & \multirow{11}{*}{\multicolumn{4}{|c|}{ 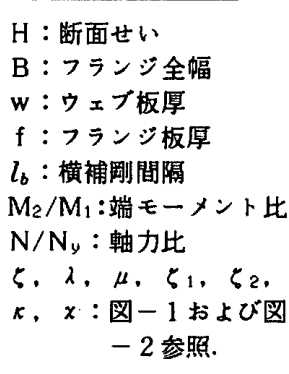 }} \\
\hline & B15E0-M1 & 479. 6 & 143. 6 & 3. 23 & & 3160 & & & 1. 32 & 0.234 & 0.781 & & & & \\
\hline & $\mathrm{B} 18 \mathrm{E} 0-\mathrm{M} 1$ & 574.6 & 144.4 & 3. 23 & & 4550 & & & 1.28 & 0.165 & 0.600 & & & & \\
\hline & C15E0-MI & 479.4 & 180.4 & 3. 23 & & 4826 & & & 1.33 & 0.159 & 0.610 & & & & \\
\hline \multirow{4}{*}{ 座 } & $\mathrm{A} 12 \mathrm{E} 4-\mathrm{H} 1$ & 539.6 & 108. 0 & 4. 44 & \multirow{6}{*}{5.89} & 1949 & \multirow{6}{*}{0.0} & 0.04 & 1.41 & 0.352 & 0.812 & & & & \\
\hline & A15E2-1/ 1 & 479. 2 & 108.1 & 3. 23 & & 2651 & & 0.02 & 1. 30 & 0.237 & 0.750 & & & & \\
\hline & B09E2-H1 & 404.8 & 143.8 & 4. 44 & & 4240 & & 0.02 & 1. 45 & 0.121 & 0.381 & & & & \\
\hline & B12E6-y1 & 539.4 & 143.8 & 4. 44 & & 2960 & & 0.06 & 1. 41 & 0.251 & 0.688 & & & & \\
\hline \multirow{5}{*}{ 屈 } & B15E4-Z1 & 479.8 & 143.6 & 3.23 & & 3159 & & 0.04 & 1. 33 & 0.233 & 0.783 & & & & \\
\hline & С18E4-H1 & 576.0 & 180.0 & 3. 23 & & 3998 & & 0.04 & 1.31 & 0.235 & 0.829 & & & & \\
\hline & $\mathrm{A} 18 \mathrm{H}-\mathrm{H1}$ & 575.6 & 108.2 & 3. 23 & \multirow{3}{*}{ 5. 89} & 1600 & \multirow{3}{*}{0.5} & \multirow{3}{*}{0.0} & 1.29 & 0.347 & 1.00 & & & & \\
\hline & $\mathrm{B} 12 \mathrm{H}-\mathrm{H1}$ & 539.0 & 143.8 & 4. 44 & & 2550 & & & 1. 36 & 0.240 & 0.792 & \multirow{2}{*}{51} & \multirow{2}{*}{\multicolumn{2}{|c|}{$\kappa$}} & \multirow{2}{*}{$x$} \\
\hline & B18H-M1 & 575.6 & 145.2 & 3. 23 & & 1600 & & & 1.39 & 0.356 & 1.00 & & & & \\
\hline \multirow{3}{*}{ 局 } & CO9E0-HI & 404.0 & 180.0 & 4.44 & \multirow{3}{*}{ 5. 89} & 3199 & \multirow{3}{*}{0.0} & \multirow{3}{*}{0.0} & 1.49 & 0.215 & 0.502 & 1.53 & \multirow{3}{*}{\multicolumn{2}{|c|}{$\begin{array}{l}1.44 \\
1.46 \\
1.46\end{array}$}} & 0.144 \\
\hline & $\mathrm{C} 12 \mathrm{E} 0-\mathbb{H I}$ & 539.2 & 180.0 & 4. 44 & & 3409 & & & 1.40 & 0.302 & 0.682 & 1. 58 & & & 0.114 \\
\hline & $\mathrm{C} 18 \mathrm{E} 0-\mathbb{H 1}$ & 575.6 & 180.1 & 3. 23 & & 4000 & & & 1.27 & 0.371 & 0.885 & 1.59 & & & 0.104 \\
\hline \multirow{2}{*}{ 部 } & $\operatorname{cog} \mathrm{E} 6-\mathrm{M} 1$ & 405.0 & 180.0 & 4.44 & \multirow{2}{*}{ 5. 89} & 3199 & 0.0 & 0.06 & 1. 45 & 0.260 & 0.611 & 1. 50 & 1. & & 0.141 \\
\hline & $\mathrm{C} 12 \mathrm{E} 2-\mathbb{M 1}$ & 540.8 & 179.5 & 4. 44 & & 3409 & 0.0 & 0.02 & 1.38 & 0.317 & 0.717 & 1.57 & 1. & & 0.112 \\
\hline 布 & A09H- 11 & 404.5 & 108.4 & 4.44 & & 1170 & & & 1.51 & 0.484 & 1.00 & 1.70 & 1. & & 0.108 \\
\hline LE & В09H-MI & 406. 2 & 144.4 & 4. 44 & & 1820 & & & 1. 46 & 0.398 & 0.918 & 1. 58 & 1. & & 0.123 \\
\hline 屎 & $\mathrm{CO} \mathrm{H}-\mathrm{H} 1$ & 404.6 & 179. 1 & 4. 44 & 5. 89 & 2750 & 0.5 & 0.0 & 1. 42 & 0.320 & 0.789 & 1. 52 & 1. & & 0.136 \\
\hline ت & $\mathrm{C} 12 \mathrm{H}-\mathrm{M} 1$ & 539.5 & 180.0 & 4. 44 & & 2160 & & & 1. 40 & 0.454 & 1.00 & 1. 57 & 1. & & 0.111 \\
\hline & C15H-H1 & 479. 2 & 180.3 & 3.23 & & 2630 & & & 1.32 & 0.433 & 1.00 & 1. 58 & 1. & & 0.119 \\
\hline
\end{tabular}

ここに, $e=f+(1-\eta) \cdot d, f:$ フランジ板厚, $L$ : 部 材端の支持点から載荷ブロック縁までの長さ。

\section{3. 解析結果および実験結果との比較}

前報 ${ }^{2)}$ の各試験体に対して解析を行った。表一 3 は, その解析条件, および解析によって得られた部材の崩壊 機構を示している。同表の崩壊機構を求めるに当たって, 荷重の最小化は, 横座屈部材では $\theta_{D}=3 \theta_{p}\left(\theta_{p}:\right.$ 全塑性 モーメント $M_{p}$ に対応する部材回転角であり,ウェブの せん断変形を考慮した弾性計算值）において行った。ま た，局部座屈部材では，局部座屈による崩壊機構 $(\nu=$ 1) を求める際は $\theta_{D}=3 \theta_{p}$ において, 座屈後の構面外変 形による崩壊機構 $(\nu=0)$ では $\theta_{D}=5 \theta_{p}$ において最小 化を行った。ここで， $\theta_{D}=3 \theta_{p}$ は，横座屈あるいは局部 座屈による変形性状が顕著に現れる部材回転角の目安, $\theta_{D}=5 \theta_{p}$ は, 局部座屈後の構面外変形が増大する部材回 転角の目安として選んだものである。

同表中, 横座屈部材において, 構面外変形による最大 横たわみ位置が， $\lambda=0.12 \sim 0.36$ (平均 0.237 ）の範囲 となっており, 実験中の観測値 $(\lambda \doteqdot 0.2 \sim 0.3)$ とほぼ 一致している。最大横たわみ位置に発生するフランジ局 部座屈の半波長については, 表中の解析値では $\zeta=1.28$ ～1.54 となっているのに対して, 実験では $\zeta=1$ 程度で あり, 解析値の方が大きくなっている。

一方, 表中の局部座屈部材において, 構面内変形によ るフランジ局部座屈の半波長は， $\zeta_{1}=1.50 \sim 1.70$ (平均 1.57）である。このことは，実験による観測值が $\zeta_{1}=1$ ２の範囲でかなりばらつくが, 平均值は 1.6 程度で
あったこと，およびウェブによる拘束を固定とした場合 の弾性理論值が $\zeta_{1}=1.68^{11)}$ であることと良く一致して いる。

図一6 $(\mathrm{a}) \sim(\mathrm{j})$ では, 解析より得られた荷重一変形曲 線を, 実験結果と比較している。図中の $(\mathrm{a}) \sim(\mathrm{f})$ が横 座屈部材であり，(g)〜 ( j) が局部座屈部材である。こ れらは，解析結果と実験結果の相関を示す代表例である。

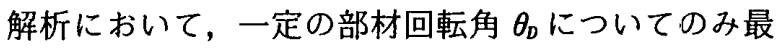
小化を行い, 崩壊機構を固定しているために，その前後 の変形域における荷重は過大評価となっている。2, 3 の試験体について, 各 $\theta_{D}$ ごとに最小化する場合と, 一 定の $\theta_{D}$ でのみ最小化する場合の解析を行い，それぞれ の荷重一変形関係を比較したが, その誤差はほとんど無 視できる程度であった。

同図の縦軸は，全塑性モーメント $M_{p}$ (軸力による低 下を考慮しない）で無次元化している。実験結果および 解析結果は，それぞれ太線および細線で表している。ま た, 横軸に平行な破線は, 前報2)に示した終局耐力の算 定値であり，次式によって与えられる。

$$
\frac{M_{u}}{M_{p}}=\left(1-\frac{N}{N_{c}}\right)\left(\frac{M_{\max }}{M_{p}}\right) \frac{F_{b}}{\sigma_{y j}} .
$$

ここに, $N_{c}=F_{c} \cdot A, F_{c}$ ：断面の平均降伏点を用いて求 めた鋼構造設計規準 ${ }^{12}$ の短期許容圧縮応力度, $A$ : 全断 面積, $M_{\max } / M_{\rho}$ : 文献 13）に示した局部座屈耐力の予 測值, $F_{b}$ : フランジの降伏点を用いて求めた規準 ${ }^{12)}$ の短 期許容曲げ応力度, $\sigma_{y f}$ : フランジの降伏点。

同図中の解析曲線において, 最大耐力以後の劣化曲線 


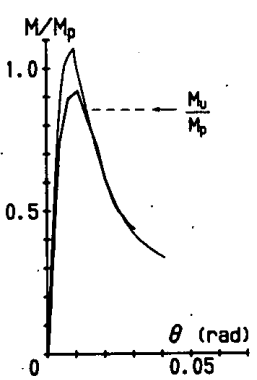

(a) $\mathrm{A} 12 \mathrm{EO}-\mathrm{M} 1$

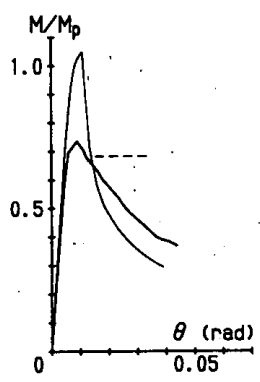

(b) A15E2-M1

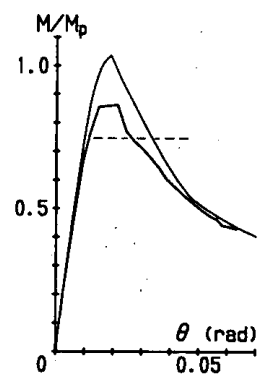

(c) B09E0-M1

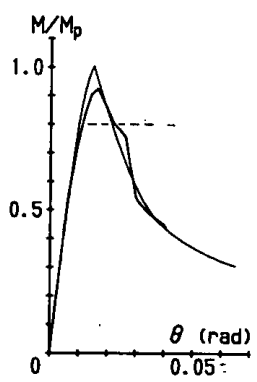

(d) B12H-M1

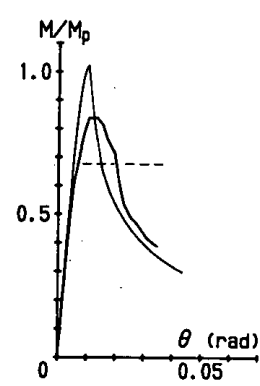

(e) B15E4-M1.

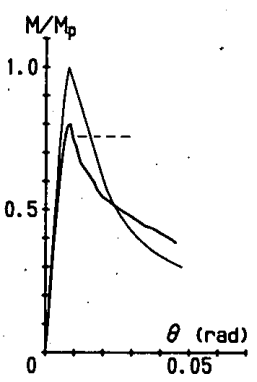

(f) $\mathrm{B} 18 \mathrm{H}-\mathrm{M} 1$

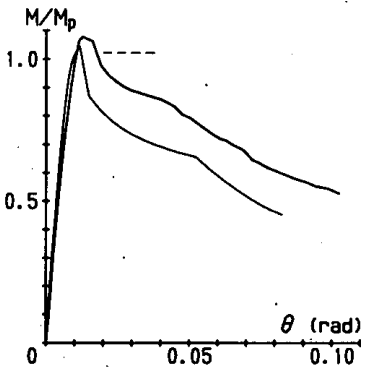

(g) $\mathrm{AOSH}-\mathrm{MI}$

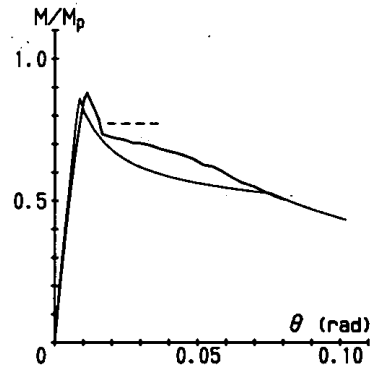

(h) COSE6-M1

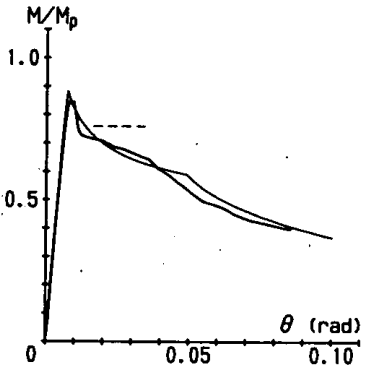

(i) C12E0-M1

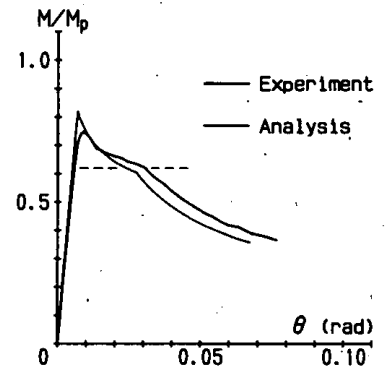

(j) C18E0-M1

図一 解析結果と実験結果の比較.

が，本研究の解析によって得られたものであり，弾性域 から最大耐力までの曲線は, 残留応力を考慮した弾塑性 解析 ${ }^{14)}$ によって求めたものである。この弾塑性解析にお いて, 残留応力分布の推定には文献 15）の方法を用い, 応力ーひずみ関係は Bilinear 型（ひすみ硬化係数 $\tau=$ $0.01)$ を仮定している。ただし，局部座屈や横座屈の影 響は考慮していない。したがって，解析曲線での最大耐 力は, 座屈による崩壊機構を仮定した剛塑性解析と, 座 屈の影響を無視した弾塑性解析との変形曲線の交点であ り, 部材酎力の上界を与える。図によると, 横座屈部材 では，解析曲線の最大耐力が実験值を大きく上回り，両 者の対応関係は認められないが，局部座屈部材での解析 値は, 実験值と同程度となっており, 部材耐力の近似値 を与えている。

局部座屈部材についての解析曲線において, 最大耐力 以後の劣化曲線に，上に凸の屈折点が生じている。これ は, 最小の耐力を与える係数 $\nu$ の值が, 急激に変化し たためである。解析によると係数 $\nu$ の変化は，部材回 転角が小さい変形域では $\nu=1$ で, 局部座屈部分での構 面内変形のみであるが，ある分岐点に達すると. $\nu=0$ に なり, 急激に構面外変形が生じるという性状を示した。 図一6に示す試験体 C 12 E 0-M 1 や C 18 E 0-M 1 など では，実験中，局部座屈後の構面外変形が急激に発生す る現象は見られなかうたが，解析曲線は実験曲線の少化 こう配の変化を良く表現している。

解析による劣化曲線は, 横座屈部材では, ウェブ幅厚 比が小さいものほど実験曲線を上回る傾向があり，局部 座屈部材では，全般に実験曲線を下回っている。また， 横座屈部材, 局部座屈部材ともに, ウェブ幅厚比が,

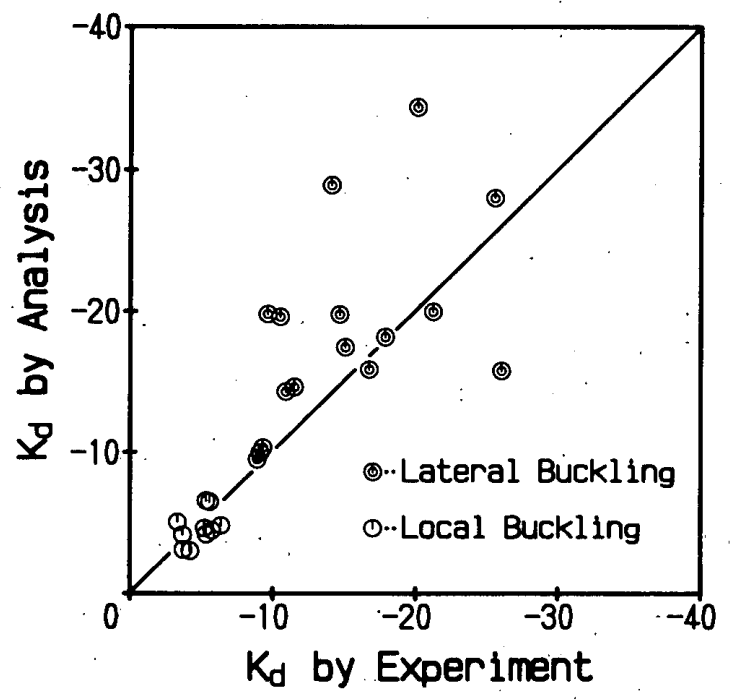

図一7 解析値と実験値の相関

120 程度で, 解析曲線と実験曲線が最も良く一致してい る。

図一7では, 劣化曲線のこう配 $K_{d}$ について, 解析值 と実験値を比較している。ここで $K_{d}$ は, 解析值および 実験值ともに，(26）式による終局耐力の算定值から， その $1 / 2$ 程度までの劣化曲線（ただし，部材回転角 $\theta \leqq 0.1$ の範囲とする) を, 最小二乗法により直線近似 して求めている。

図によると，解析曲線のこう配は，実験曲線のこう配 に対してかなりばらついているが，有意な相関関係が認 められる。局部座屈部材の解析值は, 平均すると実験値 とほほ同程度の值を与えており,横座屈部材の解析值は, 実験値よりやや大きい值を与える傾向がある。

以上より, 本解析結果は, 実験結果とおおむね良く対 


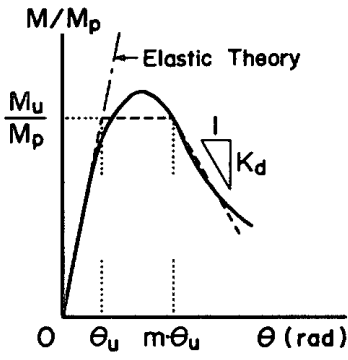

(a) Lateral buckling

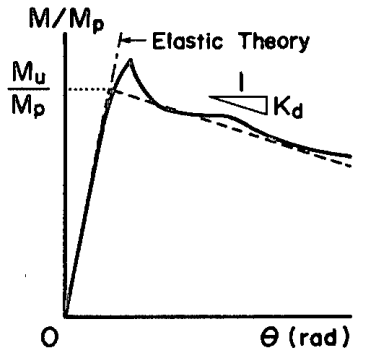

(b) Local buckling
図一8 荷重一変形曲線の単純化

応しており, 解析による劣化曲線を用いて, 最大耐力以 後の劣化こう配を推定しても差し支えないと考える。

\section{4. 荷重一変形挙動の予測}

前報2)では, (26) 式の終局曲げ耐力 $M_{u} / M_{p}$ が, 部材 耐力の下限値を与えることを示した。この終局耐力の予 測式を用いて荷重一変形曲線を表すと, 図一8の破線の ように近似することができる。

図一8(a) に示す横座屈部材の荷重一変形曲線におい て, 吸収エネルギーを正確に把握しようとすると, 変形 量 $m \cdot \theta_{u}$ の値を求めなければならないが, 実験資料が不 足しているし，解析値においても実験值との相関がほと んど認められなかったので, 実験結果の下限値程度の值 $(m \doteqdot 2)$ を用いることにする。ここに， $\theta_{u}$ は終局耐力 $M_{u}$ に対応する部材回転角の弾性計算值であり， $m$ は劣 化曲線での終局耐力 $M_{u}$ に対応する変形量の， $\theta_{u}$ に対す る倍率を表している。

図一8(b) の局部座屈部材においては, 最大耐力の直 後に急激な耐力低下を示すこと，および劣化こう配が比 較的緩やかであることから，同図のように単純化できる。

以下には，横座屈部材と局部座屈部材のそれぞれにつ いて，劣化曲線のこう配 $K_{d}$ に関する予測式を導く。ま た，これら二つの座屈形式がそれぞれ支配的となる領域 の，境界を表す夹験式を提案する。

\section{4-1 劣化こう配の予測式}

解析結果亡実験結果の比較から, 本研究で示した解析 方法により, 最大耐力以後の劣化曲線のこう配を大略把 握できることが分かった。しかし，本解析方法をそのま ま設計に応用するのは煩雑であり実用的ではないので， 解析結果の単純化を試みる。ここでは，溶接 $\mathrm{H}$ 形鎡部 材の実際的な形状，材料の降伏点，および荷重条件を考 慮した多数の解析を行い，その結果について回帰分析を 行うことによって, 劣化こう配 $K_{d}$ の予測式を導く。

i) 解析条件および回帰モデル

劣化曲線のこう配には, 部材形状, 材料の降伏点, 荷 重条件などが, 複雑に影響している。

部材形状を表すものとしては，種々のパラメータがあ るが，ここでは断面形状を表す無次元量 $d / w, b / f$, $d / b$ ，および横補剛間隔に関する無次元量 $l_{b} / d, l_{b} / b$
を選ぶ。 $l_{b} / d$ は前報 ${ }^{2} て ゙$ 考察したように, 横座屈部材の 劣化こう配と相関があり， $l_{b} / b$ は圧縮フランジの構面 外細長比に関連する量である。

また，荷重条件を表すパラメータとしては，端モーメ ント比 $M_{2} / M_{1}\left(M_{1}, M_{2}\right.$ : 横補剛区間の両端に作用する モ一メントのうち，それぞれ大きい方と小さい方），ま たはモーメント修正係数 $C_{b}=1.75-1.05\left(M_{2} / M_{1}\right)+0.3$ $\left(M_{2} / M_{1}\right)^{2}$, および軸力比 $N / N_{y}\left(N_{y}\right.$ : 全断面の降代軸力 ) を選ぶ。

これらのパラメータを変数として解析を行った。ただ し, 図一1 および図一2に示す部材の崩壊機構において, 載荷ブロックの大きさ $s$ は考えていない $(s=0) 。$

解析条件は，次のとおりである。

ウェブ幅厚比： $d / w=60,100,140,180$

フランジ幅厚比： $b / f=9,12,15$

横 補 剛間隔: $l_{b} / b=30,45,60$

（横座局部材）

$$
l_{b} / b=15,30,45
$$

（局部座㸞部材）

降伏点 $\left(\mathrm{t} / \mathrm{cm}^{2}\right): \sigma_{y}=2.4,3.0,3.6$

端モーメント比： $M_{2} / M_{1}=0.0,0.3,0.6$

軸 力 比: $N / N_{y}=0.0,0.03,0.06$

ウェブとフランジの板厚には，3.2，4.5，6，9，12 $\mathrm{mm}$ のうちのいずれかを用い，板厚の比が $1<f / w \leqq 2$ となるように板厚を組み合わせた。断面の選定は，上記 の幅厚比の条件を満たす断面の中から， $d / b$ の值が 3 10 の範囲内で, ある程度分散するように行った。

横補剛間隔に関する $l_{b} / b$ の範囲は，実験結果より， 横座屈部材に対する下限値，および局部座屈部材に対す る上限值を想定した。また，横座屈部材での上限値は， おおむね $b \doteqdot 2 \cdot i(i$ : 圧縮フランジと断面せいの $1 / 6$ か らなる T形断面のウェブ軸回りの断面 2 次半径) の関係 があることから, SS 41 部材の限界細長比 $\left(l_{b} / i=120\right)$ 程度とした。 $l_{b} / d$ の値は, 断面形状と $l_{b} / b$ の值より自 動的に定まり， $l_{b} / d=3 \sim 16$ の範囲となった。

材料の降伏点 $\sigma_{y}$ については，SS 41 材の JIS 規格下 限值が $2.4 \mathrm{t} / \mathrm{cm}^{2}$ であり, 平均値が $3.0 \mathrm{t} / \mathrm{cm}^{2}$ 程度であ る ${ }^{16)}$ ので，これらの值を用いている。また，ウェブとフ ランジの降伏点は同一としている。

これらの解析条件の組み合わせのうちで，せん断スパ ン比 $L / d$ が 8〜16の範囲を满たさないものや，終局耐 力の計算值 $M_{u} / M_{\rho}$ が 0.4 より小さくなるものは，本研 究で対象としている低層大スパン架構ではあまり用いら れないので, 解析から除外した。

以上の解析結果をもとにして, 劣化こう配 $K_{d}$ に関す る回鹵分析を行った。回帰式の独立変数には, 上記のバ ラメータを用いるが，材料の降伏点 $\sigma_{y}$ は，ヤング係数 $E$ で除して降伏ひずみ $\varepsilon_{y}$ とし，幅厚比や横補剛間隔の 


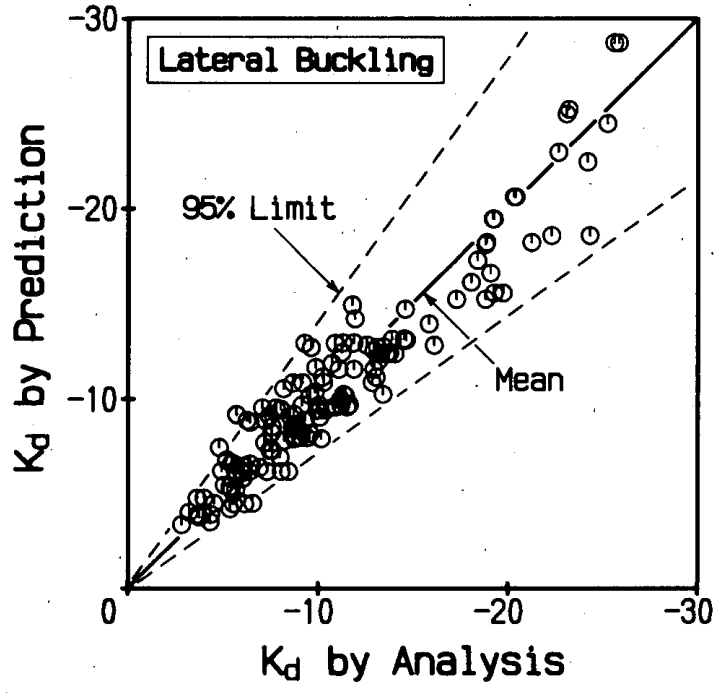

図一9（27）式による予測値と解析値の相関

パラメータに乗じて用いた。モーメント修正係数 $C_{b} に$ ついても同様に, 横補剛間隔のパラメータとともに用い た。そのほか, 劣化こう配 $K_{d}$ を説明する変数としては, 各パラメー夕間の交互作用を考慮して，二つのパラメー 夕を挂け合わせたものについても検討した。

回帰分析に用いた劣化こう配 $K_{d}$ は，(26）'式で与え られる終局酎力 $M_{u} / M_{p}$ から，その $1 / 2$ までの解析曲線 （ただし，部材回転角 $\theta \leqq 0.1$ の範囲とする）を，最小 二乗法により直線近似して求めたものである。

回帰モデルは, 対数をとり線形式とした。また, 予測 式を簡単にするために，回帰係数は 5 個とした。これら の条件のもとで, 試行錯誤で種々の数式モデルの回㷌を 行い, 変動係数および相関係数の比較において, 最も優 れた回帰式を選定した。

ii）横座屈部材の劣化こう配 $K_{d, \text { lat }}$

軸力比 $N / N_{y}$ を含むいくつかの回帰モデルに対して 変動係数を求めたが, $N / N_{y}$ を含まない場合と比較して, その変化はほとんどなかった。回帰に用いた劣化こう配 $K_{d}$ は，終局耐力 $M_{u} / M_{p}$ を用いて求められており，軸力 による $K_{d}$ の増大が, $M_{u} / M_{p}$ の低下による $K_{d}$ の娍少に よって相殺されたものと考えられる。以上の理由から， 軸力比 $N / N_{y}$ の項を省略した回帰モデルのいくつかに ついて検討した結果，次式が得られた。

$$
\begin{aligned}
K_{d, m 1}= & -\left(\frac{d}{w} \sqrt{\varepsilon_{y}}\right)^{1.20}\left(\frac{l_{b}}{d} \varepsilon_{y}\right)^{-0.394} \cdot \exp [0.433 \\
& \left.-\varepsilon_{y}\left(0.430 \frac{d}{w} \cdot \frac{b}{f}+14.8 \frac{l_{b}}{b \sqrt{C_{b}}}\right)\right] \cdots(27) \\
\operatorname{cov}= & 0.167 \quad r=0.942 \quad \text { サンプル数 }: 138
\end{aligned}
$$

ここに, $\exp []$ ：自然対数の底 $e$ に対する指数関数, $\operatorname{cov}$ ：回帰式からの資料のばらつきを表す変動係数であ り，近似的に対数值の標準偏差としている， $r$ : 相関係 数。

（27）式と解析値との相関を図一9に示す。図中の破

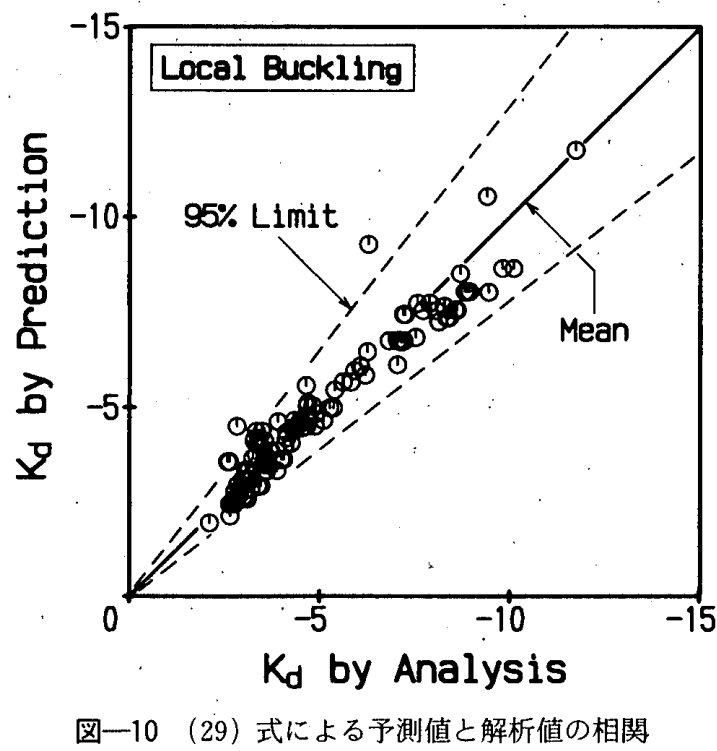

線は, 変動係数を 1.96 倍して求めた $95 \%$ 信頼限界で ある。

同図より,(27)式は解析値を良く表しているといえる。 しかし，図一7に示したように，解析值は実験值に対し てかなりばらついており，(27）式によって実験值を十 分に予測できるものではない。そこで, 安全を考慮して， (27.) 式の $95 \%$ 信頼限界によって横座屈部材の劣化こ う配を与える。したがって，

$$
K_{d, l a t}=K_{d, m 1} \cdot \exp [0.327]
$$

ここに, $K_{d, m 1}:(27)$ 式で与えられる解析による $K_{d}$ の 平均值, $K_{d, t a t}$ : 安全を考慮した横座屈部材の劣化こう 配の予測値。

iii）局部座屈部材の劣化こう配 $K_{d, l o c}$

局部座屈部材においても横座屈部材と同様に, 軸力比 $N / N_{y}$ は劣化こう配の変動を説明する主たる要因ではな かった。また，横補剛間隔に関する $l_{b} / d$ についても， 変動係数の検討から，省略が可能であっだ。試行錯誤の 結果, 最もばらつきの小さいものとして次式が得られた。

$$
\begin{aligned}
K_{d, m 2}= & -\left(\frac{d}{w} \varepsilon_{y}\right)^{0.402} \cdot \exp \left[2.64+0.118 \frac{d}{b}\right. \\
& \left.-\varepsilon_{y}\left(38.0 \frac{b}{f}+9.72 \frac{l_{b}}{b \cdot C_{b}}\right)\right] \ldots \cdots \cdots
\end{aligned}
$$

$$
\operatorname{cov}=0.127 \quad r=0.953 \text { サンプル数: } 108
$$

(28) 式と解析值との相関を図一10に示す。ここでも, 横座屈部材と同様の考察から，上式の $95 \%$ 信頼限界に よって局部座屈部材の劣化こう配を与える。

$$
K_{d, l o c}=K_{d, m 2} \cdot \exp [0.249]
$$

ここに， $K_{d, m 2}:(29)$ 式で与えられる解析による $K_{d}$ の 平均値, $K_{d, l o c}$ : 安全を考慮した局部座屈部材の劣化こ う配の予測値。

4-2 横座屈部材と局部座屈部材の判別方法

筆者らは文献 17）において，横坐屈と局部座屈がそ れぞれ支配的となる領域の境界を表す実験式を提案し 


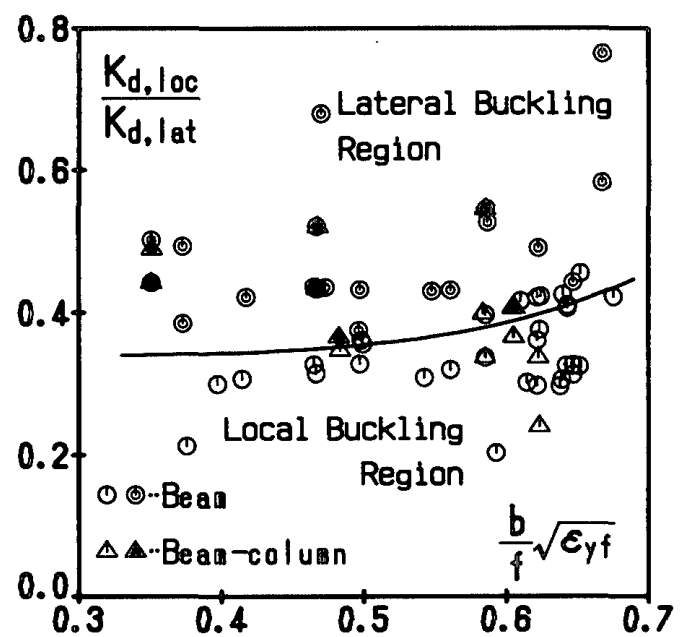

(a) $M_{2} / M_{1}=0.0$

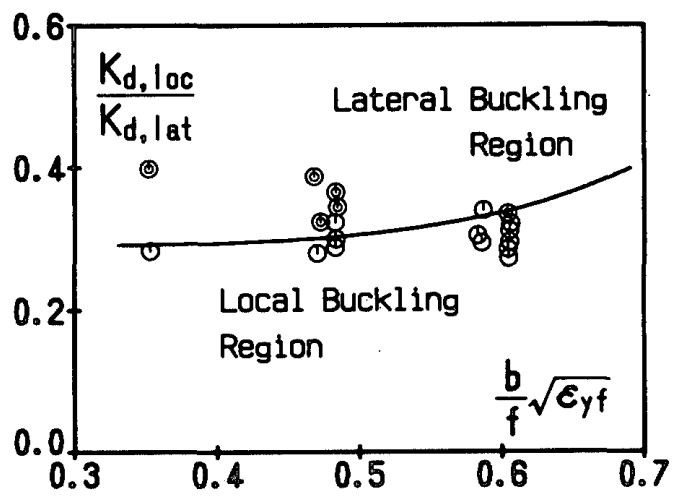

(b) $M_{2} / M_{1}=0.5$

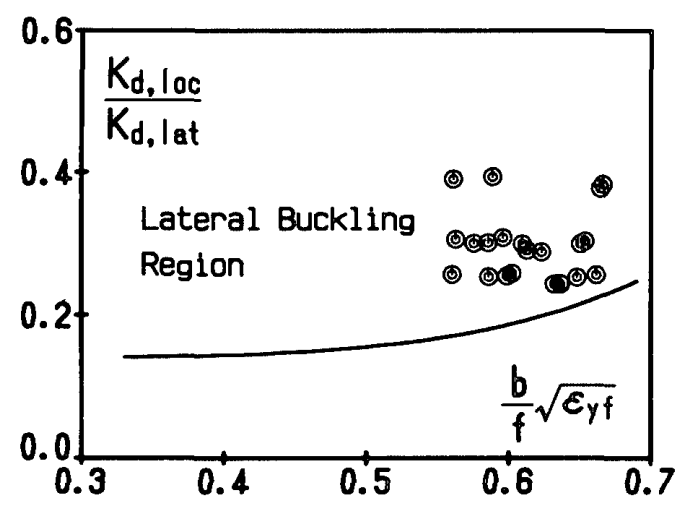

(c) $M_{2} / M_{1} \doteqdot 1.0$

図一11 横座屈領域と局部座屈領域

た。この式では, 横座屈耐力の指標となる圧縮フランジ の構面外細長比と局部座屈耐力を用いて表しており, そ れぞれの座屈耐力に着目したものといえる。この提案式 によると, 領域の境界を横補剛間隔の值として簡便に求 められる反面, フランジ幅厚比が大きく断面幅がせいに 比べて比較的大きい梁では, 横補剛間隔の境界がかなり 過小評価となることがわかっている。そこで, 最大耐力 以後の変形挙動に着目して, 横座屈部材と局部座屈部材
の境界を的確に表現する実験式を試みる。

局部座屈部材の劣化曲線では, 横座屈傾向か強くなる に従って局部座屈後の構面外変形が早期に発生すると考 えられ，劣化こう配は大きくなる。この劣化こう配があ る値以上となる場合に，横座屈によって支配されると考 えると, 劣化こう配の予測式 (28)(30) 式を用いた次の ような式によって，横座屈部材の領域を表すことができ るであろう。

$$
K_{d, \text { loc }} / K_{\alpha, \text { lat }} \geqq F(x)
$$

ここに, $F(x)$ : 任意関数または定数。

上式は, 局部座屈部材の予測值 $K_{d, l o c}$ が, 横座屈部材 としたときの予測値 $K_{\text {d.lat }}$ に対して; ある関数によって 表される比率以上になる場合に, 横座屈部材とみなすも のである。

図一11(a)〜 (c) は, $K_{d, \text { loc }} / K_{d, \text { lat }}$ とフランジ幅厚比の 関係を, 端モーメント比 $M_{2} / M_{1}$ ごとにまとめたもので ある。横軸のフランジ幅厚比は, 降伏ひずみ $\varepsilon_{y s}$ (= $\left.\sigma_{y f} / E\right)$ によって修正している。図には, 前報 ${ }^{2}$ の実験 資料のほかに，文献 17）～24）の実験資料（ただし， $\left.d / w \geqq 60, b / f \geqq 9, N / N_{y} \leqq 0.06\right)$ もプロットしてい るが，これらの試験体について $K_{d, \text { loc }}$ および $K_{d, \text { lat }}$ を求 める際， $\varepsilon_{y}$ はウェブとフランジの降伏ひずみの算術平 均としている。

図一11(a) は, $M_{2} / M_{1}=0$ の場合について示したもの) であり，軸力を加えた実験も含んでいる。図によると， 横座屈領域と局部座屈領域は比較的明瞭に区別されれ，そ の境界は図中の実線のように表すことができる。また， 軸力比が $N / N_{y} \leqq 0.06$ の低軸力下では, 軸力の, 有無に 関係なく同一の境界曲線で表されるようである。

図一11(b) は, $M_{2} / M_{1}=0.5$ の梁の実験について示し たものである。この図でも同様に，実線のような境界を 表すことができるが, この境界曲線はおおむお，同図 (a) の曲線を縦軸方向に平行移動させて与えられる。

図一11(c) は，文献 24）の実験資料をプロットした ものである。この実験では両端のみ横補剛した輋純梁に 中央集中荷重を加えている。このような梁の荷重一変形 挙動は，等モーメントを受ける梁と同じような性状を示 $す^{25)}$ ので, $M_{2} / M_{1} \doteqdot 1.0$ として同図 (a)(b) の実験資料 と比較できる。しかし，すべての試験体に横座屈が生じ ており，局部座屈領域との境界を推定することはできな い。また，本研究の解析方法では，このような梁を対象 としていないので, 解析結果に基づいた $K_{\mathrm{ad}, \text { loc }} / K_{\mathrm{d}, \text { lat }}$ は 厳密な意味を持つものではない。したがって,ここでは 一応の目安を得ようとするものである。同図 (b) と同 様に, $M_{2} / M_{1}=0$ での境界曲線を綎軸方向に平䘕移動を せると，実験資料を包含する曲線として，図中の実線の ように表される。

以上に示した 3 本の境界曲線を，一つの式に汸とめる 


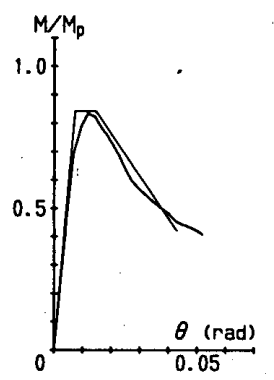

(a) A09E0-M1

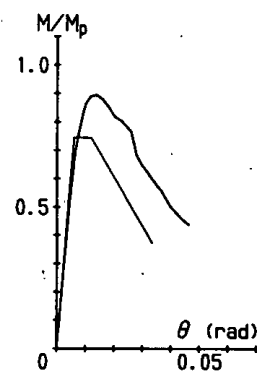

(b) B15E0-M1

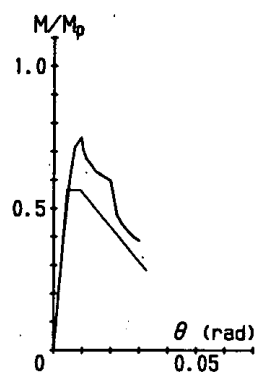

(c) C18E4-M1

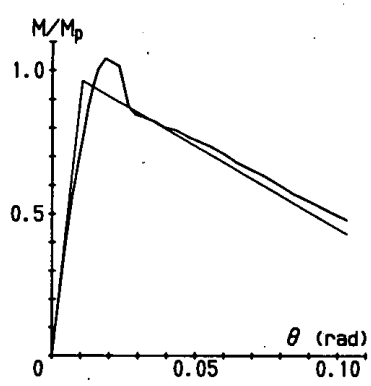

(d) $\mathrm{BOSH}-\mathrm{MI}$

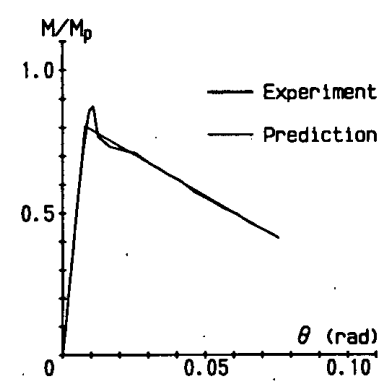

(e) $\mathrm{C} 12 \mathrm{H}-\mathrm{M} 1$
図一12 実験結果と予測結果の比較

と次式となる。

$$
\frac{K_{d, t o c}}{K_{d, l a t}}=\left(\frac{b}{f} \sqrt{\varepsilon_{y f}}\right)^{6}+C_{F}
$$

ここに, $C_{F}=0.34-0.2\left(M_{2} / M_{1}\right)^{2}$, ただし, $M_{2} / M_{1} \geqq 0$ の範囲で定義される。

(31）式からもわかるように, 上式で与えられる境界 より上の領域が横座屈部材であり,そのほかの領域が局 部座屈部材を表している。

端モーメント比 $M_{2} / M_{1}=0.5 \sim 1.0$ の実験資料が不足 しているために，この範囲の部材に対して（32）式を適 用することは基本的には不可能である。しかし，同式の $C_{F}$ は, $M_{2} / M_{1}=0$ および $M_{2} / M_{1}=0.5$ での值から外挿 的に $M_{2} / M_{1}=1.0$ での值を推定するよりも，かなり小さ くなっており，実用上の支障はないと考える。

\section{4-3 実験結果との比較}

(28)(30)(32) 式の適用性を, 前報 ${ }^{2)}$ の実験結果と比 較することによって確認する。図一12(a)～(e) は，こ れらの式および・(26) 式によって予測される荷重一変形 曲線と，実験曲線を比較した例である。

同図およびその他の実験結果との比較によると, 横座 屈部材に対する予測曲線は, 実験曲線に比べやや安全側 の評価となる。このことは，(26）式による終局耐力が 部材耐力の下限值を与えること，および耐力劣化域での 終局耐力に対応する変形量 $m \cdot \theta_{u}$ を実験結果の下限值と していることによる当然の結果といえる。

また，局部座屈部材に対する予測曲線は，図一12(d)， (e) に示すように，実験曲線とほぼ一致している。その 他の 2,3 の試験体において，(32）式による判別が横座 屈部材となったが，この場合は安全側の評価である。
以上のように，予測曲線は，実験曲線に比べて安全側 あるいは妥当な評価を与えており，ほぼ満足すべき結果 が得られている。

\section{5. 結 論}

幅厚比の大きい $\mathrm{H}$ 形断面曲げ材の変形挙動を予測する ために，降伏線理論に基づいた解析を行った。その結果， 次のことが明らかになった。

（1）本研究で行った解析の結果は，実験結果と良く 対応しており，本解析によって最大耐力以後の劣化曲線 を大略把握することができる。

（2）解析結果を単純化した（28)(30) 式によって, それぞれ横座屈部材と局部座屈部材の劣化こう配を予測 することができる。

（3）横座屈部材と局部座屈部材の領域の境界は, (32）式によって表される。

（4）前報2)で示した終局耐力の評価式 (26) 式と, 本研究で導いた予測式 (28)(30)(32) 式を用いることで, 部材の荷重一変形挙動を予測することができる。

\section{参考文献}

1）日本建築センター：構造計算指針・同解説，1986

2）與田香二, 今井克彦，黒羽啓明，小川厚治：幅厚比の大 きいH 形断面曲げ材の荷重一変形挙動に関する実験的研 究, 日本建築学会構造系論文報告集, 第 402 号, pp. 89-99, 1989.8

3）加藤 勉, 福知保長 : 板要素の変形能力について, 日本 建築学会論文報告集，第 147 号, pp. 19-25，1968.5

4) Climenhaga, J. J. and Johnson, R.P. : MomentRotation Curves for Locally Buckling Beams, Jour. of the Structural Division, ASCE, Vol.98, No.ST6, pp. 1239-1254, 1972.6

5) 三谷 勲, 牧野 稔, 松井千秋: H 形鋼柱の局部座屈後 の変形性状に関する解析的研究 (その 1,2$)$, 日本建築学 会論文報告集，第 296 号，pp. 37-47，1980.10，第 301 号， pp. $77-87,1981.3$

6) 山田 稔, 辻 文三, 山口修一：軸圧を受ける $\mathrm{H}$ 形鋼柱 の弾塑性曲け変形性状に関する研究 (VI), 日本建築学会 大会学術講演梗概集, pp.1167-1168，1980.9

7) 三谷 勲, 山崎達司：横座屈および局部座屈を伴う $\mathrm{H}$ 形 鋼部材の変形性状に関する極限解析（その1), 日本建築 学会大会学術講演梗概集, pp. 2065-2066，1981.9

8) 三谷 勲, 構面外変形を伴う $\mathrm{H}$ 形鋼柱の極限解析, 日本 建築学会九州支部研究報告, 第 30 号, pp. 213-216, 1988.3

9）田中 尚：構造物の極限解析, 建築構造学大系 9 , 彰国社, pp. 5-6, 1966.7

10) Dixon, L. C. W. (松原正一訳)：非線形最適化計算法, 培風館, pp. 72-78, 1974

11) Bleich, F. : Buckling Strength of Metal Structures, McGraw-Hill, pp. 330-331, 1952

12）日本建築学会：鋼構造設計規準, 1970

13）與田香二, 今井克彦, 黒羽啓明, 小川厚治：幅厚比の大 きい溶接 $\mathrm{H}$ 形鋼ばりの曲げ変形挙動, 日本建築学会構造 
系論文報告集，第 397 号，pp. 60-72，1989.3

14）山田 稔, 鈴木宏之：軸圧を受ける H 形鋼柱の弾塑性曲 げ変形性状に関する研究，日本建築学会近畿支部研究報 告集, pp.137-140, 1969.5

15）與田香二, 黒羽啓明, 小川厚治, 今井克彦 : 幅厚比の大 きい溶接 $\mathrm{H}$ 形龬の残留応力分布と局部座屈に関する研究, 日本建築学会九州支部研究報告, 第 30 号, pp. 221-224, 1988.3

16）日本建築学会：鋼構造塑性設計指針, p.9, 1975.11

17）今井克彦, 與田香二：局部座屈と横座屈が連成する溶接 H 形鋼の曲げ実験（その $1,2 ， 3$ ，日本建築学会大会学 術講演梗概集, pp. 1279-1283, 1984.10, pp. 699-700, 1985.10

18）加藤 勉, 秋山 宏, 帯 洋一：比較的幅厚比の大きい $\mathrm{H}$ 型断面梁の局部座屈実験, 日本建築学会大会学術講演 梗概集, pp. 1075-1076, 1976. 10

19）牧野 稔, 松井千秋, 三谷 勲：H形鋼柱の局部座屈後 の変形性状 (その1), 日本建築学会諭文報告集, 第 281 号, pp. $71-80,1979.7$

20）鈴木郎, 金子洋文, 伊藤栄俊, 加藤征宏, 佐藤裕幸 :
軽量 $\mathrm{H}$ 形鋼部材の坐屈挙動に関する研究（その2）, 日本 建築学会大会学術講演梗概集, pp.1185-1186, 1930.9

21）坂本 傑, 大竹章夫, 岩室冨二夫, 加藤征宏, 传藤裕幸 : 軽量 $\mathrm{H}$ 形鋼の曲げ変形能力, 日本建築学会大会学術講 演梗概集, pp. 2087-2088, 1981.9

22）今井克彦, 與田香二：局部座屈を伴う溶接 $\mathrm{H}$ 形銅の曲げ 実験 (その3), 日本建築学会大会学術講演梗概集, pp. 1947-1948, 1982.10

23）今井克彦, 與田香二：低軸力下で局部坐屈と横四屈が連 成する溶接 $\mathrm{H}$ 形鋼の曲げ実験, 日本建築学会大会学術講 演梗概集 C 構造 II, pp. 1085-1086, 1986.8

24）久保全弘, 福本唀士：フランジの局部座屈を伴引鋼 I 形 断面はりの横放じれ座屈, 構造工学論文集, Vol. 34A, 1988.3

25）鈴木敏郎，小野徹郎：塑性設計梁に関する実䭻的研究 （3）, 日本建築学会論文報告集, 第 175 号, pp. 69-74, 1970.9

(1989 年 10 月 10 日原稿受理, 1990 年 1 月 31 日採用決定) 